\title{
Rheology and Microbiology of Sludge from a Thermophilic Aerobic Membrane Reactor
}

\author{
Alessandro Abbà, ${ }^{1}$ Maria Cristina Collivignarelli, ${ }^{1}$ Sauro Manenti, ${ }^{1}$ Roberta Pedrazzani, ${ }^{2,3}$ \\ Sara Todeschini, ${ }^{1}$ and Giorgio Bertanza ${ }^{3,4}$ \\ ${ }^{1}$ Department of Civil and Architectural Engineering, University of Pavia, Via Ferrata 1, 27100 Pavia, Italy \\ ${ }^{2}$ Department of Mechanical and Industrial Engineering, University of Brescia, Via Branze 38, 25123 Brescia, Italy \\ ${ }^{3}$ University Research Center "Integrated Models for Prevention and Protection in Environmental and Occupational Health" \\ (MISTRAL), Department of Medical and Surgical Specialties, Radiological Sciences, and Public Health, \\ University of Brescia, Viale Europa 11, 25123 Brescia, Italy \\ ${ }^{4}$ Department of Civil, Environmental, Architectural Engineering and Mathematics, University of Brescia, \\ Via Branze 43, 25123 Brescia, Italy \\ Correspondence should be addressed to Giorgio Bertanza; giorgio.bertanza@unibs.it
}

Received 13 April 2017; Revised 21 June 2017; Accepted 27 June 2017; Published 28 August 2017

Academic Editor: Nicolas Roche

Copyright (C) 2017 Alessandro Abbà et al. This is an open access article distributed under the Creative Commons Attribution License, which permits unrestricted use, distribution, and reproduction in any medium, provided the original work is properly cited.

\begin{abstract}
A thermophilic aerobic membrane reactor (TAMR) treating high-strength COD liquid wastes was submitted to an integrated investigation, with the aim of characterizing the biomass and its rheological behaviour. These processes are still scarcely adopted, also because the knowledge of their biology as well as of the physical-chemical properties of the sludge needs to be improved. In this paper, samples of mixed liquor were taken from a TAMR and submitted to fluorescent in situ hybridization for the identification and quantification of main bacterial groups. Measurements were also targeted at flocs features, filamentous bacteria, and microfauna, in order to characterize the sludge. The studied rheological properties were selected as they influence significantly the performances of membrane bioreactors (MBR) and, in particular, of the TAMR systems that operate under thermophilic conditions (i.e., around $50^{\circ} \mathrm{C}$ ) with high MLSS concentrations (up to $200 \mathrm{gTS} \mathrm{L}^{-1}$ ). The proper description of the rheological behaviour of sludge represents a useful and fundamental aspect that allows characterizing the hydrodynamics of sludge suspension devoted to the optimization of the related processes. Therefore, in this study, the effects on the sludge rheology produced by the biomass concentration, $\mathrm{pH}$, temperature, and aeration were analysed.
\end{abstract}

\section{Introduction}

The monitoring of biological wastewater treatment processes, whatever its final goal is (assessment of compliance with effluent legal emission values, evaluation of specific stages efficiency, calculation of the maximum treatment capacity and comparison with the actual treated load, mass balance for conventional and emerging pollutants, estimation of energy consumption, etc.), is based on physical, chemical, and biological analyses. Guidelines and technical documents define the main parameters together with the proper analytical methods in case of conventional and/or nonspecific pollutants, such as the COD (chemical oxygen demand), the
BOD (biological oxygen demand), nitrogen and phosphorus compounds, surfactants, oils and greases, and suspended solids. The biological process is based on the activity of different populations of organisms set at growing levels of the detritus food web. Therefore, any tools enabling us to identify and measure the activity of these organisms provide valuable information for improving and strengthening the operation of wastewater treatment plants ([1-4] among others).

The removal capacity of specific pollutants can be assessed by performing the measurement of metabolic activity, for example, by means of ammonia uptake rate (AUR) and nitrate uptake rate (NUR) tests [5-9] and enzymatic activity quantification $[10,11]$. Besides, the microscopic observation 
of floc characteristics and the identification and quantification of filamentous bacteria allow us to highlight disturbances within their community and to foresee the occurrence of specific dysfunctions, for example, sludge foaming, bulking, and solids washout [4, 12-15]. Ecological features like specific indexes (Sludge Biotic Index (SBI), designed by [1] and Sludge Index (SI), proposed by Grupo de Bioindicación de Sevilla (GBS, Spain) [16-19]) enable plant managers to tune the operation parameters, such as sludge age, hydraulic retention time, and dissolved oxygen concentration, in order to maintain optimum conditions for the sludge biotic components.

Scientific literature reports hundreds of applications of conventional and innovative biological tools, as well as examples of investigations based on ecological criteria $[9,20-$ 27]. Almost all the biological processes have been explored in terms of biomass composition (bacteria, protozoa, metazoan, and fungi) and activity: conventional activated sludge, attached biomass, membrane reactors, and treating either municipal [27-34] or industrial wastewater [35-39]. Likewise, identification and quantification of microorganisms operating under different conditions (aerobic, anoxic, and anaerobic) have been reported [25, 40-46].

Rheological properties are crucial for activated sludge applications in wastewater treatment plants, since they severely impact the flow behaviour and many aspects that interfere with process performance and energy consumption, for example, sludge pumping, bioreactor hydrodynamics, mass transfer efficiency of aeration systems, sludge-water separation via settling, and filtration [47-54]. Due to the observed significant impact of rheology on different processes, a good knowledge of the activated sludge rheological behaviour is of great importance in both optimizing design and operation of sewage treatment plants [55]. Appropriate treatment of wastewater as a result of efficient design and operation would help in environment protection and preservation [56]. This significance motivates the recent experimental investigations and mathematical modelling on activated sludge rheology and on the impact of rheological properties on operating parameters for conventional activated sludge plants (e.g., [57-59]) and for membrane bioreactors MBRs (e.g., $[51,60,61])$.

Basically, rheology of a sludge is defined by its viscous characteristics, which can be determined by the relationship between shear rate and shear stress, obtained through a rheological measurement (which imposes either shear rate or shear stress [62-64] and measures alternatively these parameters). The observed relationship is strictly related to the characteristics of the sludge, such as the relative concentration of water and suspended matter due to the nature of the wastewater and to the treatment process that is subjected to [65].

At lower concentration of the suspended matter, sludge's behaviour can be reasonably approximated to a Newtonian fluid characterized by a linear relation between shear stress and rate of deformation, with the proportionality coefficient being the fluid viscosity. The measured viscosity is rather independent from shear rate, at given values of temperature and pressure. The flow curve is therefore a straight line through the origin of the coordinate axes.
As the particulate concentration increases, the sludge deviates from Newtonian behaviour. For a non-Newtonian liquid, the measured viscosity becomes dependent on the rate of shear, and the so-called apparent viscosity is introduced which is defined as the ratio between shear stress and shear rate at a given point of the flow curve. The apparent viscosity allows us to interpret the external and internal interaction forces between the constituents of the sludge that influences its rheological behaviour [51]. A highly concentrated sludge exhibits yield stress that is the critical stress triggering plastic deformation of the material continuum. Under the yield stress, no significant flow can be detected. According to [49], the yield stress can be related to reciprocal interactions among the suspended solid particles opposing to the deformation. There are two types of yield stress: static and dynamic. Static yield stress can be measured in an undisturbed sample, while dynamic yield stress refers to a perturbed sample and is extrapolated from its equilibrium flow curve as shear rates approach zero. It has been reported that the static yield stress was not observed at a mixed liquor suspended solid (MLSS) concentration equal to $16 \mathrm{~g} / \mathrm{L}$, probably because at this concentration the static yield stress almost equals the dynamic yield stress [51].

The rheological characterization of non-Newtonian fluids leads to practical difficulties; different measurement protocols and devices (i.e., capillary rheometers as in [66] and rotational rheometers as in [67]) have been adopted to study the rheological properties and a wide variety of models have been proposed. Widely used non-Newtonian relationships between shear stress and shear rate for activated sludge are the Ostwald de Vaele model, the Bingham model, the Herschel and Bulkley model, and the Casson model $[49,68]$. All these models belong to the category of time-independent rheological models for which the relation between stress and applied shear rate does not depend upon the duration of shearing.

The properties of activated sludge, such as MLSS concentration, particle size distribution and shape, interaction among particles, flocculation ability, and surface physicochemical characteristics, all have effects on rheology and, thus, on the kind of model most efficient in describing the sludge rheological profile and on the values of the preferable model parameters $[49,69]$.

A number of studies demonstrate that also temperature significantly affects the rheological characteristics: sludge becomes progressively more fluid as the temperature increases due to thermal $[65,70,71]$. These studies also prove that temperature irreversibly modifies the sludge structure.

This paper reports the results of an integrated study performed on the sludge deriving from a real scale TAMR, supplied with pure oxygen (being the average dissolved oxygen concentration of the mixed liquor equal to $2.3 \mathrm{mg} \mathrm{L}^{-1}$, while minimum and maximum values equal 0.2 and $15.0 \mathrm{mg} \mathrm{L}^{-1}$, resp.) located at a facility for the treatment of solid and highstrength liquid wastes. The sludge has been characterized in terms of microbiological and rheological features. Actually, the authors found, previously, links between the amount of filamentous bacteria and zooglea clusters and viscosity values of mixed liquors from conventional activated plants treating municipal wastewater, thus suggesting the use of rheological 


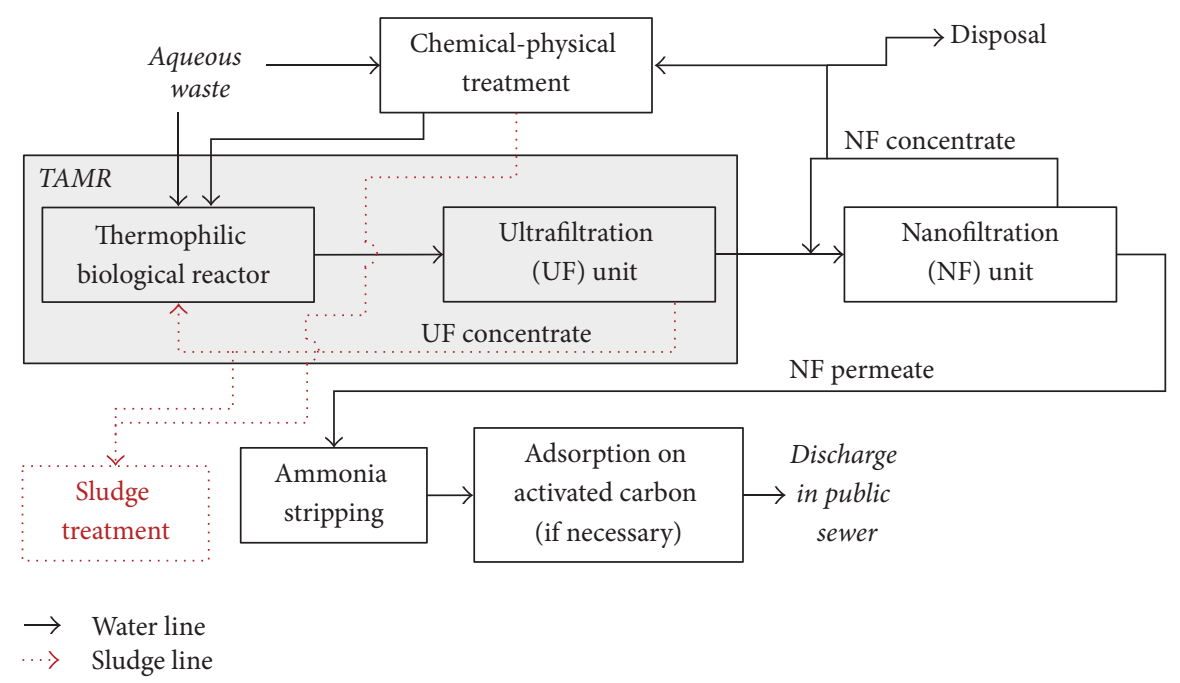

Figure 1: Process scheme of the studied facility.

tools to control dysfunctions caused by the proliferation of specific microorganism [72].

TAMRs operate at $45^{\circ} \mathrm{C}$ and are profitably applied for the treatment of high-strength wastewater deriving from food processing, pulp, and paper and pharmaceutical factories [73-76]. Recently, their extension to sludge treatment has been explored [77]. In effect, an aerobic thermophilic biomass is characterized by a lower yield, hence a decrease in specific sludge production (down to $0.02 \mathrm{~kg} \mathrm{SSV} / \mathrm{kg} \mathrm{COD}_{\text {removed }}$ ). Furthermore, other valuable advantages consist in faster chemical reaction rates, increased organics solubility, high process stability, that is, the prompt activity recovery after operational changes, capability of degrading high salinity and biorecalcitrant wastewater, and possibility of integrating the thermophilic stage, as a pretreatment into a combined scheme, thus improving the removal extent of organic substances $[76,78,79]$. Nevertheless, despite the aforementioned advantages, thermophilic processes are still rarely adopted at the real scale $[80,81]$.

This research was aimed, therefore, at exploring the rheological and microbiological features of TAMR biomass, which remain almost obscure, in spite of the increasing knowledge gained about its excellent performances.

\section{Materials and Methods}

A synthetic description of the studied waste treatment facility, together with sampling and analytical procedures, is presented.

2.1. The Waste Treatment Facility. The facility is located in Northern Italy and treats 60,000 t/y of solid and liquid highstrength COD wastes (except mutagens and carcinogens); since fifteen years ago, this technology has been investigated in detail by [80].

Figure 1 depicts the scheme of the unit fed with liquid wastes: the main phase consists in the TAMR (see [80] for a complete description).
Before entering the biological tank, metals are removed by means of a chemical-physical treatment which leads to their precipitation as ammonium salts, hydroxides, and phosphates (pH equal to 11 units). The TAMR surface is $267 \mathrm{~m}^{2}$ wide; net volume is about $1000 \mathrm{~m}^{3}$.

Pure oxygen is supplied through static mixers, yielding oversaturation of the sewage, which is recirculated within them. Ultrafiltration unit includes two parallel lines consisting in a feeding pump, a recirculation pump, and three channels of ceramic membranes (each containing 99 tubular membranes having 25 channels). Pores size allows retaining molecules larger than 0.3 microns and with a molar mass higher than $300 \mathrm{kDa}$. Minimum and maximum operation pressure values are 3 and 5 bar, respectively.

The average concentrations of pollutants inlet to the TAMR are $25,000 \mathrm{mgCOD} \mathrm{L}^{-1}, \quad 1200 \mathrm{mg} \mathrm{TN} \mathrm{L}^{-1}$, and $700 \mathrm{mg} \mathrm{TP} \mathrm{L}^{-1}$. The TAMR performances, in terms of COD, TN, and TP removal yields, are $78 \%, 80 \%$, and $90 \%$, respectively. The high removal yields for $\mathrm{TP}$, as reported by [79], are due to the chemical precipitation: this phenomenon could be due to the dosage of lime (in the chemical-physical treatment before the TAMR), but the most important aspect is ascribed to the aeration of reactor that promotes the phosphorus crystallization.

2.2. Characterization of Sludge. Samples taken from the TAMR were submitted to investigations aimed to define their microbial profiles and rheological behaviour.

2.2.1. Microbial Community Investigation. Mixed liquor samples were taken from TAMR and freighted immediately to the laboratory at $4^{\circ} \mathrm{C}$. After adding absolute ethanol (Sigma Aldrich), (1:1) mixed liquor was pipetted onto a glass slide and allowed to dry at $46^{\circ} \mathrm{C}$ for 15 minutes; afterwards, samples were submitted to fluorescent in situ hybridization (FISH), according to prescriptions of VIT ${ }^{\circledR}$ (Vermicon AG, Munich, Germany) gene probe technology, based on fluorescent labelled DNA probes. Only viable microorganisms 


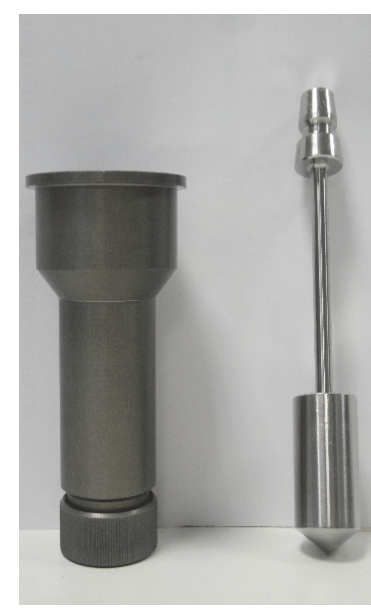

(a)

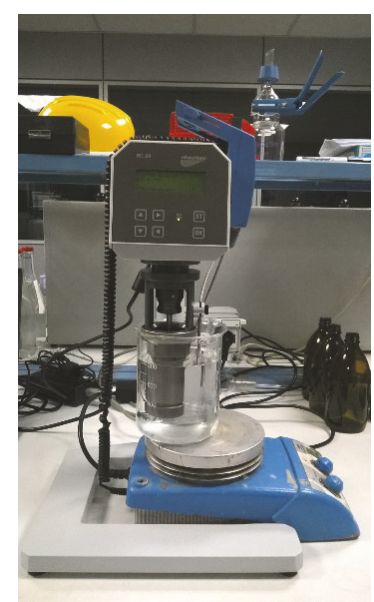

(b)

FIGURE 2: Experimental apparatus: coaxial cylinder CC25DIN (a) and rheometer RC20 (b).

are identified, quantified, and even visualized in their environment. The major advantage of this method is that the analysis is based on the stable genetic material of the cells and not dependent on phenotypic features which may be quite variable among bacteria. Moreover, as the target of the gene probes is the rRNA of the cells, only viable bacteria can be detected. As fluorescent signal intensities are correlated with the rRNA content within the cells, a further result on the physiological activities of the detected cells can be obtained. The detection limit is about 1000 cells $\mathrm{mL}^{-1}$. A process of image analysis enabled the quantification of single populations, by comparing the signals of each group with the fluorescence emitted by the all the viable microorganisms.

Besides, observation of floc features and identification and abundance assessment of filamentous bacteria were performed according to [12]. In particular, the analyses were performed by using a Zeiss Axiostar Plus microscope under phase contrast illumination. Raw samples were firstly examined: afterwards, due to their conspicuous density, they were diluted with the supernatant $(1: 10$ and $1: 100)$ in order to enable the visualization of single flocs. Their morphology was registered (according to [12]), by considering the shape (irregular, round), the firmness, and the mean diameter. For this purpose, 10 microscopy fields were considered as replicates; flocs diameter was measured by employing a graduated slide as a reference. This tool was used also for measuring the length of filamentous bacteria. Likewise, the effects of filaments on floc structure, their abundance (with respect to each floc), and the presence of other important factors, such as free cells in suspension, inorganic/organic particles, and zoogleas, were recorded.

Mixed liquor samples were also submitted to the analysis of the microfauna for the calculation of the Sludge Biotic Index (SBI) according to [1] (microscopic observation under direct illumination; magnification: 100x).

2.2.2. Rheological Tests. The rheological experiments were carried out using rheometer RC20 (RheoTec) with a configuration CC25DIN of coaxial cylinders (Figure 2(a)): spindle radius: $12.5 \mathrm{~mm}$; internal radius of the measuring cylinder: $13.56 \mathrm{~mm}$.

The working principle of the instrument is based on this aspect: the sliding of the sludge in the cavity between the coaxial cylinders, due to the spindle rotation with a fixed share rate, while the external cylinder is held, requires a torque that is measured by the instrument. Several rotational tests with different controlled shear rate (CSR) were performed to obtain the rheological equation:

$$
\tau=f(\dot{\gamma}),
$$

where $\tau$ is the shear stress $[\mathrm{Pa}]$ and $\dot{\gamma}$ is the share rate $\left[\mathrm{s}^{-1}\right]$.

The temperature was controlled by the use of water in a beaker placed on a heating magnetic stirrer (Figure 2(b)).

In Table 1, the details of rheological test are summarized (the $\mathrm{pH}$ and temperature values represent the average data recorded during the tests). The tests were carried out on two samples of thermophilic biomass with different concentrations of total solids (TS). The $\mathrm{pH}$ values are between 6.6 and 9.1 (sulphuric acid and soda were used) and the temperature is close to $45^{\circ} \mathrm{C}$.

The biomass samples withdrawn from the TAMR were delivered to the laboratory within $120 \mathrm{~min}$ after sampling. They were stored (for $180 \mathrm{~min}$ ) at $45^{\circ} \mathrm{C}$ under different conditions: a first subsample was not submitted to aeration; a second subsample was kept in aeration conditions by an air compressor at lab scale $\left(1 \mathrm{~L}_{\text {air }} \mathrm{min}^{-1}\right)$; only for the tests on sample $\mathrm{B}$, a third subsample was aerated with an air flow of $0.5 \mathrm{~L}_{\text {air }} \min ^{-1}$.

Each rheological test was performed with fixed shear rates that were maintained for 300 seconds; shear rate was increased step by step as reported in Table 1. Shear stress and apparent viscosity were recorded every $30 \mathrm{~s}$ (ten data sets for each share rate).

Both the sludge samples presented in Table 1 were tested starting from an imposed shear rate of $100 \mathrm{~s}^{-1}$ with a step increment of $100 \mathrm{~s}^{-1}$ (or $50 \mathrm{~s}^{-1}$ in some cases). Anyway, the adopted rheometer was unable to resolve the shear 
TABLE 1: Rheological tests performed: operative conditions.

\begin{tabular}{|c|c|c|c|c|c|}
\hline \multirow{2}{*}{ Test \# } & & \multicolumn{3}{|c|}{ Operative conditions } & \multirow{2}{*}{$\begin{array}{c}\text { Shear rate } \\
\qquad\left[\mathrm{s}^{-1}\right]\end{array}$} \\
\hline & & Average $\mathrm{pH}$ & Average temperature $\left[{ }^{\circ} \mathrm{C}\right]$ & Aeration & \\
\hline \multirow{6}{*}{$\begin{array}{l}\text { Sample A } \\
\left(150 \text { gTS L }^{-1}\right)\end{array}$} & 1 & 6.7 & 44.5 & $\mathrm{~N}$ & $700,800,900,1000$ \\
\hline & 2 & 6.7 & 45.2 & $\mathrm{Y}$ & $700,800,900,1000$ \\
\hline & 3 & 7.7 & 45.1 & $\mathrm{~N}$ & $700,800,900,1000$ \\
\hline & 4 & 8.3 & 45.3 & $\mathrm{Y}$ & $750,800,900,1000$ \\
\hline & 5 & 9.0 & 45.1 & $\mathrm{~N}$ & $750,800,850,900,1000$ \\
\hline & 6 & 9.1 & 44.9 & $\mathrm{Y}$ & $800,850,900,1000$ \\
\hline \multirow{9}{*}{$\begin{array}{l}\text { Sample B } \\
\left(190 \text { gTS L }^{-1}\right)\end{array}$} & 7 & 7.0 & 45.4 & $\mathrm{~N}$ & $500,600,750,900,1000$ \\
\hline & 8 & 6.7 & 45.3 & $1 / 2$ & $500,600,750,900,1000$ \\
\hline & 9 & 6.6 & 45.0 & $\mathrm{Y}$ & $500,600,750,900,1000$ \\
\hline & 10 & 7.8 & 44.9 & $\mathrm{~N}$ & $500,600,750,900,1000$ \\
\hline & 11 & 8.3 & 45.2 & $1 / 2$ & $500,600,750,900,1000$ \\
\hline & 12 & 8.4 & 45.3 & $\mathrm{Y}$ & $500,600,750,900,1000$ \\
\hline & 13 & 8.9 & 45.0 & $\mathrm{~N}$ & $500,600,750,900,1000$ \\
\hline & 14 & 9.0 & 45.3 & $1 / 2$ & $500,600,750,900,1000$ \\
\hline & 15 & 9.1 & 45.0 & $\mathrm{Y}$ & $500,600,750,900,1000$ \\
\hline
\end{tabular}

$\mathrm{N}$ : no aeration; $1 / 2$ : limited aeration $\left(0.5 \mathrm{~L}_{\text {air }} \min ^{-1}\right)$; $\mathrm{Y}$ : full aeration $\left(1 \mathrm{~L}_{\text {air }} \min ^{-1}\right)$.

stress for values below $700 \mathrm{~s}^{-1}$ for the lower concentration $\left(150 \mathrm{gTS} \mathrm{L}^{-1}\right)$ and, respectively, for values below $500 \mathrm{~s}^{-1}$ for the higher concentration $\left(190 \mathrm{gTS} \mathrm{L}^{-1}\right)$.

It is worth noting that in the present study a limited number of shear rates has been investigated (i.e., four values for tests 1-4 and 6, and five in case of tests 7-15). This aspect, in principle, may represent an inherent limitation of the work that, however, has the merit to provide a first insight into the rheological behaviour of a highly concentrated thermophilic sludge. Furthermore, the preliminary findings (see Section 3.2) show that the trend of the flow curves exhibits a certain degree of reliability, as confirmed by the regression coefficient displayed in Table 3. Anyway, a more refined investigation by increasing the range of explored shear rates and the amount of samples will be useful to clarify some issues concerning the effects of aeration on the rheological behaviour and will be included in the next steps of the research.

\section{Results and Discussion}

This chapter gathers the information obtained from the microbiological and the rheological analyses and sets them in the scientific literature context.

3.1. Microbiological Features of Thermophilic Sludge. The sludge appeared extremely thick, due to the great suspended solids concentration maintained in the TAMR $\left(150-200 \mathrm{~g} \mathrm{~L}^{-1}\right)$. Figure 3 is a micrograph (100x magnification) of the mixed liquor, characterized by a huge amount of inorganic particles (clusters of salts and hydroxides). Flocs are almost absent and bacterial cells are free in the liquor.

Based on the characterization rules of [12], the mean floc diameter was $<150 \mu \mathrm{m}$. Flocs could be classified as irregular

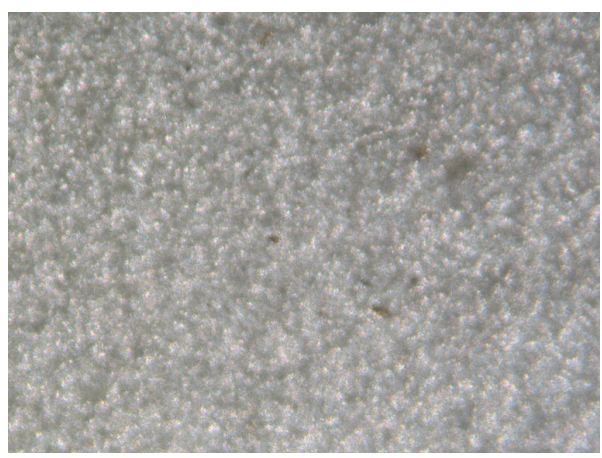

FIgURE 3: Micrograph of the raw sample (magnification: 100x).

and diffuse. Filamentous bacteria abundance belonged to class I (few, which means that filaments are observed only in an occasional floc), according to the distinction proposed by [12], who identified six different cases, based on the average number of filamentous bacteria located in a single floc. Neither zoogleas nor spirochaetes were observed. Likewise, Protozoa and Metazoa were completely absent (as noticed by [78]): therefore, the Sludge Biotic Index (SBI) could not be calculated.

These findings tally with the outcome reported in the scientific literature: a poor (or even lacking) flocculation is usually seen to occur under thermophilic conditions [78, 82-84].

About the amount of filamentous bacteria, however, [83] observed filamentous abundances ascribable to class IV (very common) and class $\mathrm{V}$ (abundant), while [85] reported two cases, where filaments reach class IV, with their growth being inversely proportional to the hydraulic retention time. 
The paper [78] puts forward several hypotheses to explain the lack of flocculation: firstly, the absence of floc forming microorganisms (such as zoogleas, not found also in the present case, as previously mentioned); secondly, the impossibility to reach the physiological state enabling the flocculation; finally, the establishment of medium conditions interfering with flocculation and coagulation. Further assumptions are made by authors in [84] who ascribed the scarce flocculation to the high shear sensitivity of the thermophilic floc, which becomes prone to erosion; they also suggest a possible influence of decreased cell hydrophobicity.

Table 2 presents the results of FISH analyses, while Figure 4 highlights the percentages of detected taxa over the total bacterial population. Only three major bacteria groups were found with higher shares (Betaproteobacteria, Gammaproteobacteria, and Cytophaga-Flexibacter). Two further major groups (Deltaproteobacteria and Chloroflexi) were quantified with very low shares and the other groups were completely absent, indicating very limiting conditions for typical wastewater treatment plant bacteria. The FISH analyses confirmed the nearly total absence of filamentous bacteria. Furthermore, physiological groups like nitrifying bacteria were completely absent. Such a profile is quite unusual for a mesophilic activated sludge and can be attributable to temperature conditions and wastewater characteristics, which trigger a very special composition of the population. Actually, the above-mentioned factors, together with plant running strategies, can be nowadays linked with the growth of specific bacterial populations and the achievement of a particular physiological state [86-88]; on the other hand, this is even more true in the case study, where temperature is constantly maintained at $45^{\circ} \mathrm{C}$, and the influent sewage consists in high-strength COD wastes.

Betaproteobacteria were the dominant group in the sludge sample. They were detected with a remarkable high share of $77 \%$ of the total viable bacteria. No filaments or ammonium oxidizing bacteria belonging to this class were observed, as found by [78]. Almost the complete population was formed by members of the $\beta 1$-group. All organisms of this group showed bright fluorescence signals indicating a good physiological status of the cells. Levels up to $25 \%$ of this group are considered as normal in industrial wastewater treatment plants. Gammaproteobacteria were measured with an unusual high share of $15 \%$ in comparison to typical wastewater sludge values. In effect, normally, this group does not exceed a share of $10 \%$. Here, they appeared mainly as thin long rod-shaped bacteria with middle fluorescence signals indicating a moderate physiological activity of the cells. No characteristic filaments of this group like Thiothrix or Eikelboom type $021 \mathrm{~N}$ were found. The authors in [88] postulated that these cocci possess weak flocculation properties (at least a subgroup of Gammaproteobacteria): also their abundance might be related to the presence of small flocs.

The share of members of the Cytophaga-Flexibacter subphylum was $4 \%$ of the total viable flora, which corresponds more or less to typical values in activated sludge, which can reach a percentage of $10 \%$. The thin rod-shaped cells showed low fluorescence signals. Filaments like Haliscomenobacter hydrossis were not detected.

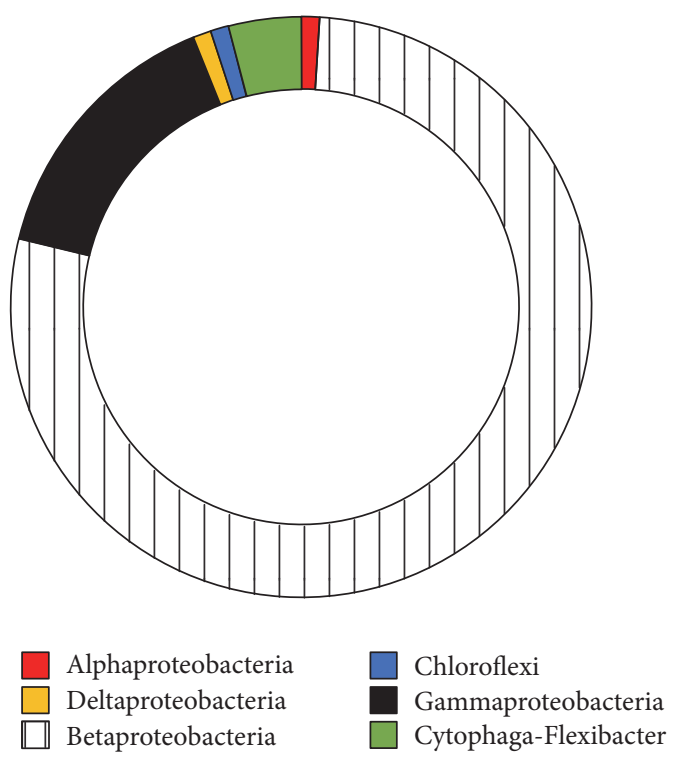

Figure 4: Pie chart of the detected taxa shares.

Alphaproteobacteria were detected with a share of only $1 \%$ and appeared completely as coccus-shaped uniform cells. Shares of up to $20 \%$ of this group are quite normal for industrial activated sludge.

Members of the Chloroflexi genus were measured with a very low share of $<1 \%$ in the sample. The single filaments had a length of about $50 \mu \mathrm{m}$. In wastewater treatment plants, $10-20 \%$ of this group are quite common. Chloroflexi bacteria in WWTPs showed increased shares over the last years; they cause bulking and foaming events if huge abundances are reached.

Deltaproteobacteria, including most sulphate-reducing bacteria, were represented as uniform single cells, with a share of $<1 \%$. Values of up to $8 \%$ for this group can be found in the mixed liquor of plants treating industrial wastewater. All other main bacteria groups including filamentous bacteria were not detected.

High values for total cell counts (dead and alive) were determined, with $2.5 \cdot 10^{10} \mathrm{~mL}^{-1}$ and total viable cell counts with $5.0 \cdot 10^{9} \mathrm{~mL}^{-1}$, which is larger than the total viable cell counts of up to $1-3 \cdot 10^{9} \mathrm{~mL}^{-1}$ usually detected in industrial wastewater activated sludge treatment plants.

Figures 5-7 clearly show the structure of the sludge, consisting basically in clusters of salts and hydroxides and free cells.

3.2. Rheological and Statistical Analysis of Activated Sludge. Several analytical models have been proposed to mimic the rheological behaviour of biological sludge, each with different degree of complexity depending on the number of the parameters contained [68]. Most of these models can be mathematically described by a power-low curve including an offset to account for yield stress.

In the paper [51], the rheological characteristics of an activated sludge sampled in a pilot MBR system, with a MLSS concentration varying between $2.74 \mathrm{~g} \mathrm{~L}^{-1}$ and $16 \mathrm{~g} \mathrm{~L}^{-1}$, were 
TABLE 2: Results of the application of the VIT gene probes.

\begin{tabular}{|c|c|c|c|}
\hline \multirow[t]{2}{*}{$\begin{array}{l}\text { Analysed target } \\
\text { microorganism(s) }\end{array}$} & \multirow[t]{2}{*}{ Physiological features } & \multicolumn{2}{|c|}{$\begin{array}{l}\text { Share of each group in relation to the } \\
\text { overall bacteria population (\%) }\end{array}$} \\
\hline & & Species & Group \\
\hline $\begin{array}{l}\text { Alphaproteobacteria } \\
\text { (amount of filamentous } \\
\text { bacteria) }\end{array}$ & $\begin{array}{l}\text { Group with high amount of heterotrophic organisms (e.g., } \\
\text { genera Paracoccus, Sphingomonas, Rhizobium, Caulobacter, and } \\
\text { Rhodospirillum) }\end{array}$ & & $\begin{array}{c}1 \\
(\text { n.d. })\end{array}$ \\
\hline Alysiosphaera & $\begin{array}{l}\text { Group consisting of filamentous bacteria similar to Nostocoida } \\
\text { limicola II, with typical chain structures. Responsible for } \\
\text { bulking sludge in industrial wastewater treatment plants }\end{array}$ & n.d. & \\
\hline $\begin{array}{l}\text { Betaproteobacteria } \\
\text { (amount of filamentous } \\
\text { bacteria) }\end{array}$ & $\begin{array}{l}\text { Group consisting of the } \beta 1 \text {-group (many filamentous bacteria) } \\
\text { and of the } \beta 2 \text {-group (most ammonia oxidizing bacteria). In } \\
\text { municipal WWTPs, mostly the dominating group (e.g., genera } \\
\text { Burkholderia, Sphaerotilus, Alcaligenes, Thiobacillus, and } \\
\text { Nitrosomonas) }\end{array}$ & & $\begin{array}{l}77 \\
\text { (n.d.) }\end{array}$ \\
\hline $\begin{array}{l}\beta 1 \text {-group of the } \\
\text { Betaproteobacteria } \\
\text { (amount of filamentous } \\
\text { bacteria) }\end{array}$ & $\begin{array}{l}\text { Group consisting of floc forming bacteria and } S \text {. natans related } \\
\text { filamentous bacteria }\end{array}$ & $\begin{array}{l}76 \\
(\text { n.d. })\end{array}$ & \\
\hline $\begin{array}{l}\text { Gammaproteobacteria } \\
\text { (amount of filamentous } \\
\text { bacteria) }\end{array}$ & $\begin{array}{l}\text { Group consisting of heterotrophic, mixotrophic, and } \\
\text { autotrophic microorganisms (e.g., genera Acinetobacter, } \\
\text { Aeromonas, Pseudomonas, Vibrio, and Thiothrix) }\end{array}$ & & $\begin{array}{l}15 \\
\text { (n.d.) }\end{array}$ \\
\hline Acinetobacter & $\begin{array}{l}\text { Filamentous and nonfilamentous bacteria. Common in } \\
\text { municipal and industrial WWTPs with a relatively high sludge } \\
\text { age. Favoured by scarce dissolved oxygen concentration }\end{array}$ & n.d. & \\
\hline Thiothrix & $\begin{array}{l}\text { Filamentous sulphur bacterium, favoured by nutrient deficiency. } \\
\text { Adapted to low dissolved oxygen concentration }\end{array}$ & n.d. & \\
\hline Eikelboom type $021 \mathrm{~N}$ & $\begin{array}{l}\text { Filamentous sulphur bacterium common in municipal and } \\
\text { industrial WWTPs. favoured by nutrient deficiency. Adapted to } \\
\text { low dissolved oxygen concentration }\end{array}$ & n.d. & \\
\hline $\begin{array}{l}\text { Deltaproteobacteria } \\
\text { (amount of filamentous } \\
\text { bacteria) }\end{array}$ & $\begin{array}{l}\text { Group including most sulphate reducing bacteria (e.g., families } \\
\text { Desulfobacteraceae, Desulfobulbaceae, and } \\
\text { Desulfovibrionaceae) }\end{array}$ & & $\begin{array}{c}<1 \\
\text { (n.d.) }\end{array}$ \\
\hline $\begin{array}{l}\text { Chloroflexi } \\
\text { (amount of filamentous } \\
\text { bacteria) }\end{array}$ & $\begin{array}{l}\text { Group of filamentous organisms with increasing impact on } \\
\text { municipal and industrial WWTPs, due to their contribution to } \\
\text { foaming and bulking events, very stable against mechanical } \\
\text { stress (genus Herpetosiphon, type 1851, type 0803, and type } 0092 \\
\text { and many other filaments still unknown) }\end{array}$ & & $\begin{array}{c}<1 \\
\text { (n.d.) }\end{array}$ \\
\hline Eikelboom type 1851 & $\begin{array}{l}\text { Filamentous bacterium; contribution to sludge bulking. } \\
\text { Favoured by nutrient deficiency }\end{array}$ & n.d. & \\
\hline Herpetosiphon aurantiacus & Filamentous bacterium. Aerobic and anaerobic conditions & n.d. & \\
\hline $\begin{array}{l}\text { Cytophaga-Flexibacter } \\
\text { subphylum } \\
\text { (amount of filamentous } \\
\text { bacteria) }\end{array}$ & $\begin{array}{l}\text { Group containing filamentous and floc forming bacteria. Mainly } \\
\text { in WWTPs with nutrients removal (e.g., genera Cytophaga, } \\
\text { Flavobacterium, and Flexibacter), }\end{array}$ & & $\begin{array}{c}4 \\
\text { (n.d.) }\end{array}$ \\
\hline $\begin{array}{l}\text { Haliscomenobacter } \\
\text { hydrossis }\end{array}$ & $\begin{array}{l}\text { Filamentous bacterium; contribution to sludge bulking. } \\
\text { Favoured by high sludge age, low dissolved oxygen } \\
\text { concentration, and high ammonia concentration }\end{array}$ & n.d. & \\
\hline $\begin{array}{l}\text { Planctomycetes } \\
\text { (amount of filamentous } \\
\text { bacteria) }\end{array}$ & $\begin{array}{l}\text { Group, mainly in municipal WWTPs; members of this group } \\
\text { are involved in the ANAMMOX process. Adapted to low } \\
\text { dissolved oxygen concentration (e.g., genera Planctomyces, } \\
\text { Pirellula, Isosphaera, and Scalindua) }\end{array}$ & & n.d. \\
\hline $\begin{array}{l}\text { Candidatus Nostocoida } \\
\text { limicola type III }\end{array}$ & Filamentous bacterium; contribution to sludge bulking & n.d. & \\
\hline
\end{tabular}


TABle 2: Continued.

\begin{tabular}{|c|c|c|c|}
\hline \multirow[t]{2}{*}{$\begin{array}{l}\text { Analysed target } \\
\text { microorganism(s) }\end{array}$} & \multirow[t]{2}{*}{ Physiological features } & \multicolumn{2}{|c|}{$\begin{array}{l}\text { Share of each group in relation to the } \\
\text { overall bacteria population (\%) }\end{array}$} \\
\hline & & Species & Group \\
\hline $\begin{array}{l}\text { Actinobacteria } \\
\text { (amount of filamentous } \\
\text { bacteria) }\end{array}$ & $\begin{array}{l}\text { Group of GRAM positive bacteria with a high DNA GC content. } \\
\text { Several problematic filamentous bacteria like Microthrix } \\
\text { parvicella and nocardioforms. In WWTPs with nutrients } \\
\text { removal (also biological phosphorous removal) }\end{array}$ & & n.d. \\
\hline Microthrix parvicella & $\begin{array}{l}\text { Filamentous bacterium; in WWTPs with nutrients removal. } \\
\text { Contribution to sludge bulking, floating, and foaming. Strong } \\
\text { hydrophobic characteristics }\end{array}$ & n.d. & \\
\hline Nocardioforms & $\begin{array}{l}\text { Group containing filamentous and floc forming bacteria. } \\
\text { Contribution to sludge bulking, floating, and foaming. Strong } \\
\text { hydrophobic characteristics }\end{array}$ & n.d. & \\
\hline $\begin{array}{l}\text { Candidatus Nostocoida } \\
\text { limicola type II }\end{array}$ & $\begin{array}{l}\text { Typical chain structures. Contribution to sludge bulking. In } \\
\text { municipal WWTPs }\end{array}$ & n.d. & \\
\hline $\begin{array}{l}\text { Firmicutes } \\
\text { (amount of filamentous } \\
\text { bacteria) }\end{array}$ & $\begin{array}{l}\text { Group of GRAM positive bacteria with a low DNA GC content. } \\
\text { Several fermentative bacteria like the genera Streptococcus, } \\
\text { Bacillus, and Lactobacillus }\end{array}$ & & n.d. \\
\hline $\begin{array}{l}\text { Candidatus Nostocoida } \\
\text { limicola type I }\end{array}$ & Filamentous bacterium. Contribution to sludge bulking & n.d. & \\
\hline Candidatus TM7 & $\begin{array}{l}\text { Group recently detected, including filamentous bacteria like } \\
\text { Eikelboom type } 0041\end{array}$ & & n.d. \\
\hline $\begin{array}{l}\text { Group of ammonia } \\
\text { oxidizing bacteria (AOB) }\end{array}$ & For example, genera Nitrosomonas and Nitrosococcus & & n.d. \\
\hline $\begin{array}{l}\text { Group of nitrite oxidizing } \\
\text { bacteria (NOB) }\end{array}$ & For example, genera Nitrobacter and Nitrospira & & n.d. \\
\hline $\begin{array}{l}\text { Phosphate accumulating } \\
\text { organisms (PAO) }\end{array}$ & $\begin{array}{l}\text { Responsible for the biological phosphorus removal (e.g., } \\
\text { Candidatus Accumulibacter phosphatis) }\end{array}$ & & n.d. \\
\hline $\begin{array}{l}\text { Glycogen accumulating } \\
\text { organisms (GAO) }\end{array}$ & Candidatus Competibacter phosphatis & & n.d. \\
\hline
\end{tabular}

examined. These authors showed that Herschel-Bulkley model provides suitable fitting of experimental data for shear rate above $25 \mathrm{~s}^{-1}$.

Proper fitting of the experimental data analysed in this work (MLSS concentrations in the range $150-190 \mathrm{~g} \mathrm{~L}^{-1}$ ) was obtained with Herschel-Bulkley model which is recognized to be more efficient in describing the overall rheological behaviour of sludge with high solid concentration [65]:

$$
\tau=\tau_{y}+K \dot{\gamma}^{n}
$$

In (2), the two fitting parameters are the consistency coefficient $K$ and the flow behaviour index $n$. As explained in the following, yield stress $\tau_{y}$ was not considered as a fitting parameter of the flow curve.

Several statistical descriptors can be adopted to measure the accuracy of prediction of rheological models and the reliability of their estimated parameters [65]. In this work, the coefficient of determination (or regression coefficient) $R^{2}$ and the standard error of the estimate $\sigma_{\text {est }}$ in (3) were adopted according to [51]

$$
\sigma_{\text {est }}=\left[\sum_{i=1}^{N} \frac{\left(y_{i}-y_{\mathrm{pre}}\right)^{2}}{N-2}\right]^{1 / 2} .
$$

In (3), $N$ denotes the number of samples included in the population of the stochastic variable $y$ (i.e., $N$ is the number of measures contained in the data set of each test carried out at a given shear rate, temperature, $\mathrm{pH}$, and aeration), while $y_{\text {pre }}$ is the corresponding predicted value obtained through the following linear regression equation:

$$
\begin{aligned}
& y=a x+b, \\
& y=\log \left(\tau-\tau_{y}\right), \\
& x=\log (\dot{\gamma}), \\
& a=n, \\
& b=\log (K) .
\end{aligned}
$$

The linearized flow equation for the regression analysis, denoted by the first equation of (4), contains three rheological parameters of the sludge that are the consistency coefficient $K$, the flow behaviour index $n$, and the yield stress $\tau_{y}$ that may be, in general, different from zero.

The method of ordinary least squares (OLS) was adopted for linear regression for fitting the dependence of shear stress versus shear rate.

As well known, only two of the three above-mentioned model parameters can be reliably estimated through linear 


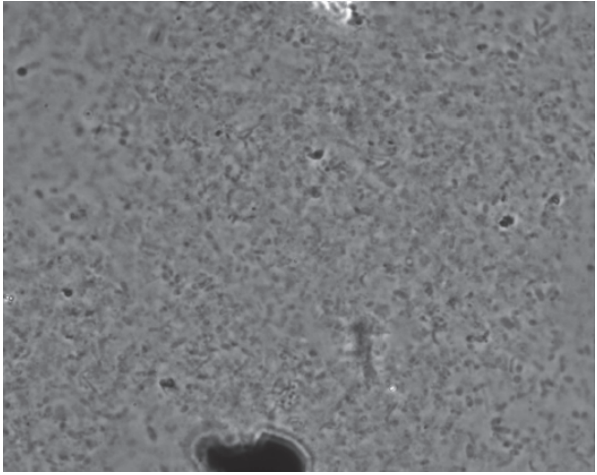

(a)

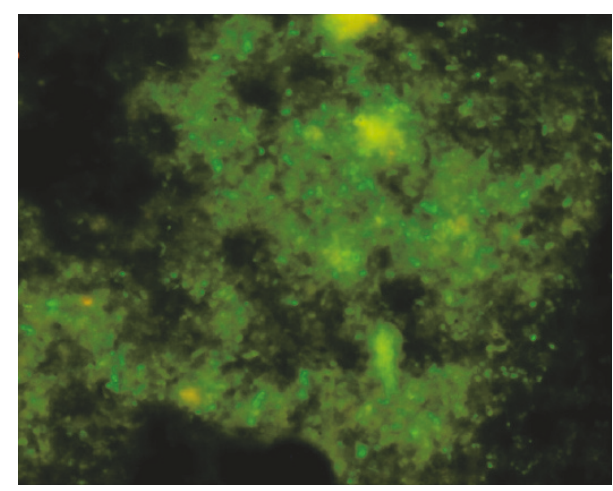

(b)

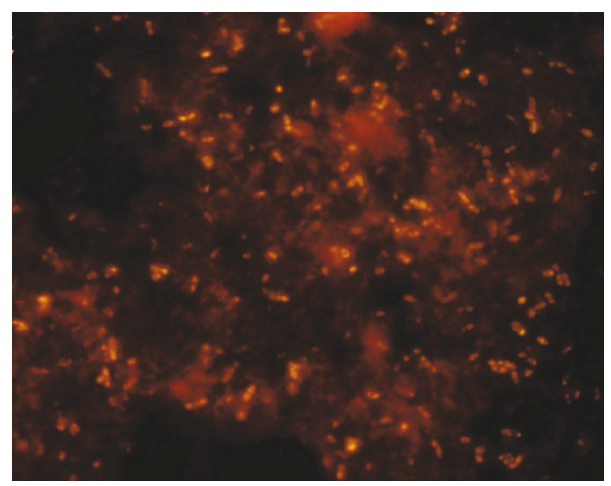

(c)

FIGURE 5: Micrographs (magnification: 1000x) of the flocs under phase contrast and epifluorescence. Comparison of the same floc area. Hybridization target: viable bacteria and Betaproteobacteria. (a) Phase contrast. Identical microscopic fields under fluorescence: (b) detection of all viable bacteria and (c) analysis with a specific probe for Betaproteobacteria.

regression. Therefore, in the following statistical analysis, it was assumed as fitting parameters the flow behaviour index $n$ and the consistency coefficient $K$ that are included in the two parameters $a$ and $b$ of the linear equation (see (4)). However, the proper value of yield stress should be estimated in order to fit experimental data in all testing conditions.

In some works, the yield stress $\tau_{y}$ has been determined through graphical extrapolation of the flow curve [51]. Owing to the above-mentioned lack of experimental data below the shear rate of $500 \mathrm{~s}^{-1}$, in the present study, an alternative procedure for the estimate of $\tau_{y}$ was adopted, as explained below.

In each test, when carrying out the linear regression of the experimental data with respect to the unknown parameters $K$ and $n$, the yield stress was considered as a deterministic parameter ranging in the interval [0.0-3.9] $\mathrm{Pa}$ at steps of $0.05 \mathrm{~Pa}$ : for each of these values statistical estimates of both $a$ and $b$ were obtained along with the corresponding value of the regression coefficient $R^{2}$. The value of the yield stress that, for each test, maximizes the regression coefficient was assumed as an estimate of $\tau_{y}$.

The obtained results of the statistical analysis are summarized in Table 3 for both concentrations of suspended solid.

The results obtained for both MLSS concentrations show that the flow behaviour index $n$ was greater than one; at the lower MLSS concentration of $150 \mathrm{~g} \mathrm{~L}^{-1}$, the sludge exhibited shear-thickening (dilatant) behaviour, with the estimated yield $\tau_{y}$ stress equal to zero.

For all the tests carried out, the apparent viscosity increased, at any shear rate, with the solid content; moreover, the differences in apparent viscosity measured at different shear rates increased with solid content, in accordance with [89]. This rheological behaviour was different from the shear-thinning (pseudo-plastic) behaviour noticed by [51] for MBR sludge samples with suspended solid concentration not exceeding $16.0 \mathrm{~g} \mathrm{~L}^{-1}$. In the present study, however, the MLSS concentration was about one order of magnitude higher. The interactions between the sludge particles were expected to be even more intense and therefore one might have expected a nonzero yield stress [89]. In fact, as the particle concentration increases, they became progressively more close to each other, thus leading to a rapid growth of the number of interactions that opposes to deformation.

Anyway, such a dilatant behaviour may be related to the fact that in this work the sludge samples were tested at very high temperature of about $45^{\circ} \mathrm{C}$, which is unusual if one considers that generally the testing temperature does not exceed $35^{\circ} \mathrm{C}$ [68].

In order to point out possible temperature effects on the obtained results, the work by [65] can be considered which investigated the rheology of mixed primary and secondary sludge as a function two critical parameters affecting flow 
TABLE 3: Summary of rheological tests and results of linear regression analysis.

\begin{tabular}{lccccccccc}
\hline Test \# & $\begin{array}{c}\text { Average } T \\
{\left[{ }^{\circ} \mathrm{C}\right]}\end{array}$ & $\begin{array}{c}\text { Average } \mathrm{pH} \\
{[-]}\end{array}$ & Aeration & $\begin{array}{c}\text { MLSS } \\
{\left[\mathrm{gTS} \mathrm{L}^{-1}\right]}\end{array}$ & $\begin{array}{c}\tau_{y} \\
{[\mathrm{~Pa}]}\end{array}$ & $\begin{array}{c}n \\
{[-]}\end{array}$ & $\begin{array}{c}K \\
{\left[\mathrm{~Pa} \mathrm{~s}{ }^{n}\right]}\end{array}$ & $\begin{array}{c}R^{2} \\
{[-]}\end{array}$ \\
\hline 1 & 44.5 & 6.7 & $\mathrm{~N}$ & & 0.0 & 2.760 & $1.992 e-8$ & 0.997 & 0.0296 \\
{$[-]$} & 0.0 & 2.909 & $6.805 e-9$ & 0.971 \\
2 & 45.2 & 6.7 & $\mathrm{Y}$ & & 0.0944 \\
3 & 45.1 & 7.7 & $\mathrm{~N}$ & 150 & 0.0 & 2.976 & $4.474 e-9$ & 0.965 & 0.1066 \\
4 & 45.3 & 8.3 & $\mathrm{Y}$ & & 0.0 & 3.120 & $1.642 e-9$ & 0.967 & 0.0905 \\
5 & 45.1 & 9.0 & $\mathrm{~N}$ & & 0.0 & 2.138 & $1.125 e-6$ & 0.923 & 0.0711 \\
6 & 44.9 & 9.1 & $\mathrm{Y}$ & & 0.0 & 2.925 & $4.080 e-9$ & 0.953 & 0.0706 \\
\hline 7 & 45.4 & 7.0 & $\mathrm{~N}$ & & 2.35 & 5.307 & $3.824 e-16$ & 0.986 & 0.2107 \\
8 & 45.3 & 6.7 & $1 / 2$ & & 1.95 & 3.901 & $6.532 e-12$ & 0.992 & 0.1146 \\
9 & 45.0 & 6.6 & $\mathrm{Y}$ & & 2.05 & 3.508 & $9.316 e-11$ & 0.989 & 0.1199 \\
10 & 44.9 & 7.8 & $\mathrm{~N}$ & & 1.90 & 4.433 & $1.60 e-13$ & 0.998 & 0.0646 \\
11 & 45.2 & 8.3 & $1 / 2$ & 190 & 1.65 & 3.452 & $1.711 e-10$ & 0.994 & 0.0875 \\
12 & 45.3 & 8.4 & $\mathrm{Y}$ & & 1.70 & 3.590 & $6.253 e-11$ & 0.992 & 0.1091 \\
13 & 45.0 & 8.9 & $\mathrm{~N}$ & & 1.40 & 4.585 & $6.285 e-14$ & 0.998 & 0.0651 \\
14 & 45.3 & 9.0 & $1 / 2$ & & 1.60 & 5.468 & $1.469 e-16$ & 0.998 & 0.0791 \\
15 & 45.0 & 9.1 & $\mathrm{Y}$ & & 1.25 & 5.221 & $8.227 e-16$ & 0.998 & 0.0852 \\
\hline
\end{tabular}

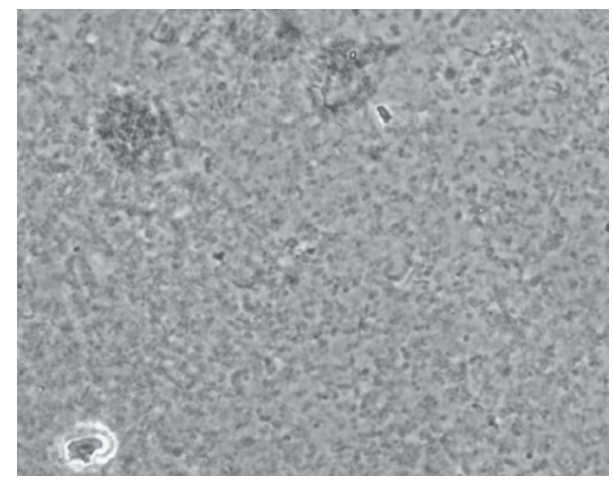

(a)

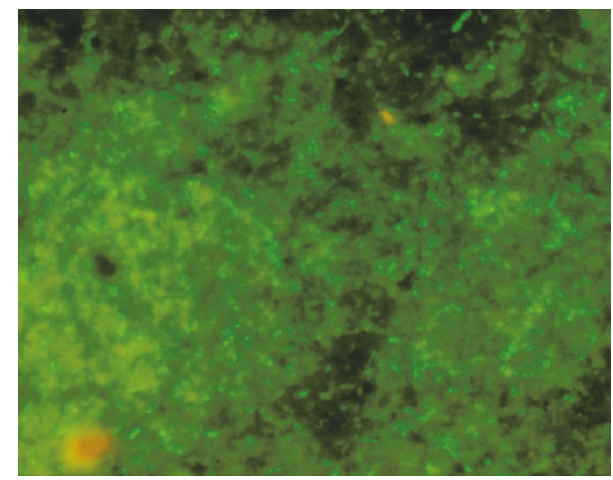

(b)

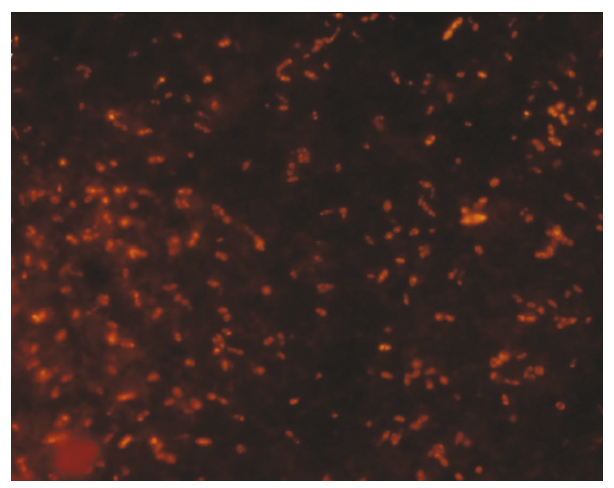

(c)

Figure 6: Micrographs (magnification: 1000x) of the flocs under phase contrast and epifluorescence. Comparison of the same floc area. Hybridization target: viable bacteria and $\beta 1$, Betaproteobacteria. (a) Phase contrast. Identical microscopic fields under fluorescence: (b) detection of all viable bacteria and (c) analysis with a specific probe for $\beta 1$-group of Betaproteobacteria.

behaviour: temperature, ranging between $25^{\circ} \mathrm{C}$ to $55^{\circ} \mathrm{C}$, and solid concentration, varying between $4.3 \%$ and $9.8 \%$ that is quite below the total solid content investigated in this work.

These authors have shown that (for a given solid concentration) yield stress depends exponentially on the inverse of the temperature. Therefore, an increase of the testing temperature seems consistent with a relevant reduction of the yield stress.

It is worth noting that in all tests with suspended solid concentration of MLSS $=150 \mathrm{~g} \mathrm{~L}^{-1}$ when imposing a shear 


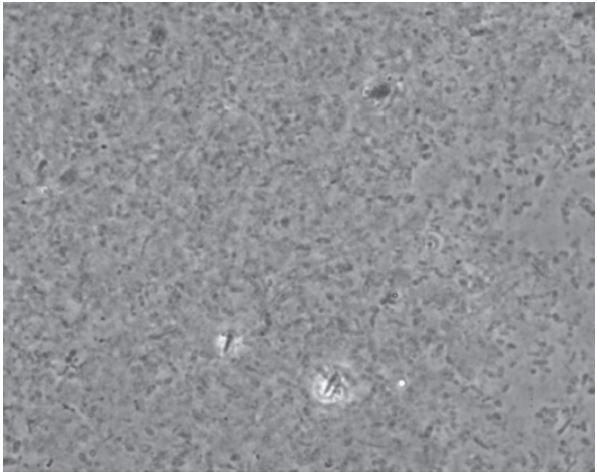

(a)

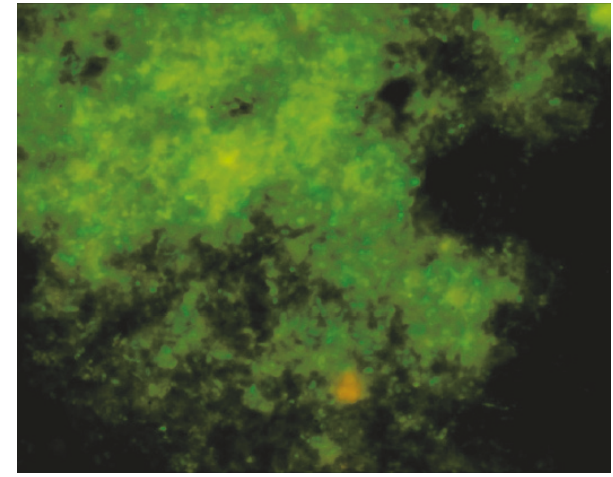

(b)

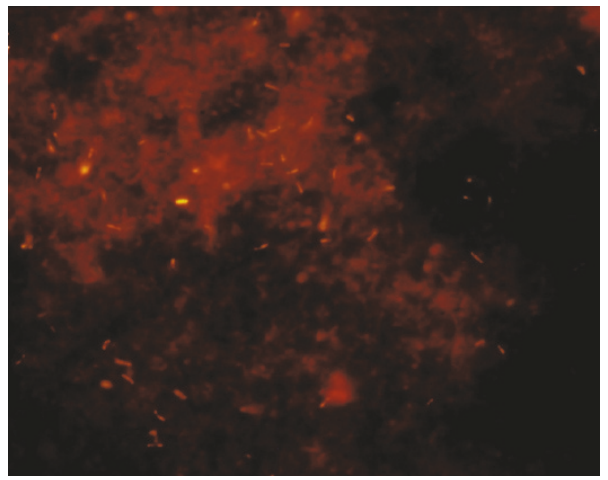

(c)

FIGURE 7: Micrographs (magnification: 1000x) of the flocs under phase contrast and epifluorescence. Comparison of the same floc area. Hybridization target: viable bacteria and Gammaproteobacteria. (a) Phase contrast. Identical microscopic fields under fluorescence: (b) detection of all viable bacteria and (c) analysis with a specific probe for Gammaproteobacteria.

rate below $100 \mathrm{~s}^{-1}$ the measured shear stress was under the minimum value that can be resolved by the rheometer (see Section 2.2.2). Indeed, the assumption of a zero yield stress appears quite plausible.

At this stage of investigation, the flow properties of all the sludge samples were tested at a shear rate greater than or equal to $500 \mathrm{~s}^{-1}$. This is due to technical reasons related to the modelling of particular operating conditions of concern in the treatment plant. From a theoretical point of view, the experimental points below the shear rate value of $500 \mathrm{~s}^{-1}$ may influence the extrapolation of the yield stress for the analysed samples; for this reason, further studies will be carried out to investigate this aspect.

In the work by [65], it has been noticed that (for a given temperature) yield stress increases almost linearly with solid concentration. This seems in accordance with the experimental results obtained for the higher solid concentration (MLSS) of $190 \mathrm{~g} \mathrm{~L}^{-1}$ that showed significant shear stress values even at the lower shear rate (see Figures 9(a) and 9(b) and Table 3). In this case, proper fitting of the experimental points requires nonzero yield stress to be considered in the mathematical model of the flow curve in (2).

Suitable values were obtained for the regression coefficient in all tests. The best fitting of the adopted mathematical model is obtained for the higher MLSS concentration of
$190 \mathrm{~g} \mathrm{~L}^{-1}$, as confirmed by the values of $R^{2}$ for the tests from 7 to 15 in Table 3.

Concerning the lower MLSS concentration of $150 \mathrm{~g} \mathrm{~L}^{-1}$, the minimum value of $R^{2}=0.923$ was obtained for the test number 5 and was however combined with a relatively small value of the standard error of the estimate $\sigma_{\text {est }}$. In the remaining tests at the same concentration, the regression coefficient was significantly higher, and for the test case number 1, the best fitting was obtained.

In the paper by [51], it has been shown that, by varying the mathematical model to represent the rheological behaviour of the sludge sample, the correlation coefficient may fall below 0.9 and $\sigma_{\text {est }}$ may rise to 0.9 at high concentrations of suspended solids. Further investigations may thus be carried out to assess if the result obtained for test number 5 might be influenced by the selected mathematical model. Anyway, the interpolating curve obtained for test number 5 (see Figure 8) seems quite acceptable for technical purposes in the engineering management of treatment plants where several sources of uncertainty may commonly affect the predictions.

Figures 8 and 9 show, for each rheological test, the flow curves (blue) calculated from the linear regression; the corresponding experimental data are plotted with red plus markers along with symmetric error bars $2 \cdot \sigma_{\tau}$ long, where 


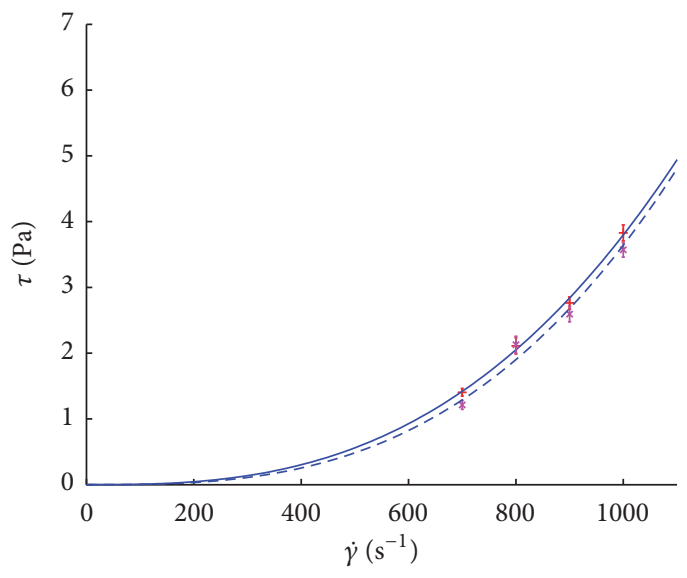

$+\quad$ Exper $T=44.5^{\circ} \mathrm{C}-\mathrm{pH}=6.7-\operatorname{air} \mathrm{N}$

— Calc $T=44.5^{\circ} \mathrm{C}-\mathrm{pH}=6.7-\operatorname{air} \mathrm{N}$

$\times \quad$ Exper $T=45.2^{\circ} \mathrm{C}-\mathrm{pH}=6.7-\operatorname{air} \mathrm{Y}$

- - Calc $T=45.2^{\circ} \mathrm{C}$ - $\mathrm{pH}=6.7$ - air $\mathrm{Y}$

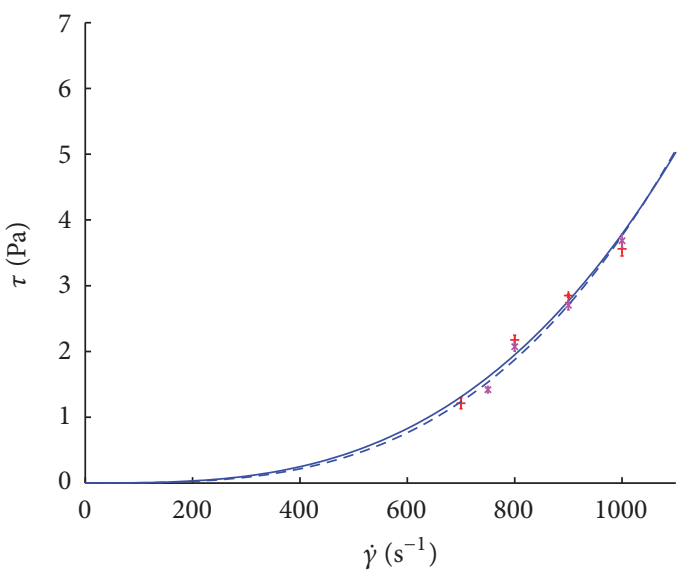

$+\quad$ Exper $T=45.1^{\circ} \mathrm{C}-\mathrm{pH}=7.7-\operatorname{air} \mathrm{N}$

- Calc $T=45.1^{\circ} \mathrm{C}-\mathrm{pH}=7.7-$ air N

$\times \quad$ Exper $T=45.3^{\circ} \mathrm{C}-\mathrm{pH}=8.3-$ air $\mathrm{Y}$

- - Calc $T=45.3^{\circ} \mathrm{C}-\mathrm{pH}=8.3-$ air $\mathrm{Y}$

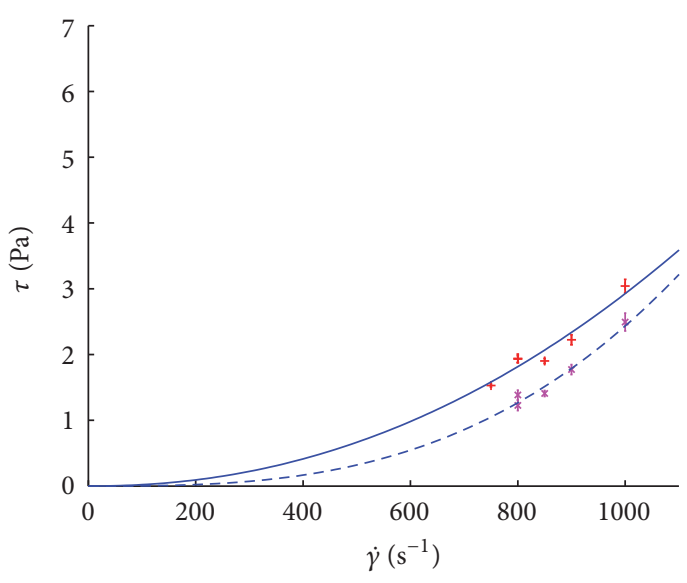

$+\quad$ Exper $T=45.1^{\circ} \mathrm{C}-\mathrm{pH}=9.0-\operatorname{air} \mathrm{N}$

— Calc $T=45.1^{\circ} \mathrm{C}-\mathrm{pH}=9.0-\operatorname{air} \mathrm{N}$

$\times \quad$ Exper $T=44.9^{\circ} \mathrm{C}-\mathrm{pH}=9.1-\operatorname{air} \mathrm{Y}$

-- Calc $T=44.9^{\circ} \mathrm{C}-\mathrm{pH}=9.1-\operatorname{air} \mathrm{Y}$

FIGURE 8: Shear stress versus rate of deformation (MLSS $150 \mathrm{~g} \mathrm{~L}^{-1}$ ): comparison between experimental and calculated values. $\sigma_{\tau}$ is the standard deviation of the shear stress measurements obtained with the rheometer at each shear rate value.

Figure 8 plots the results obtained for the MLSS concentration of $150 \mathrm{~g} \mathrm{~L}^{-1}$. For a given $\mathrm{pH}$ value, the aeration of the sludge sample (air Y) led, in general, to a reduction of apparent viscosity (hence, of the shear stress) at any shear rate with respect to the corresponding test on nonaerated samples (air N). This behaviour is clearly evident in the case with $\mathrm{pH}$ around 9.0 (lower panel) where, in the investigated shear rate range, the aeration of the sample produced a significant reduction of the shear stress that reaches $0.55 \mathrm{~Pa}$ at some shear rates between $700 \mathrm{~s}^{-1}$ and $1000 \mathrm{~s}^{-1}$. At smaller $\mathrm{pH}$ values, the $\mathrm{Y}$ and $\mathrm{N}$ curves are very close to each other and the above-mentioned shear stress reduction may be caused by interpolation uncertainties connected to the low number of experimental points, rather than being connected to the aeration. This aspect deserves further investigation.

Obtained results seem however reasonable, since aeration of the sludge may lead to bubble entrapment into the bioaggregate that increases the mean distance between suspended solid particles and consequently weaken the interactions between them; this lowers both apparent viscosity and shear stress at any shear rate. Such an effect is clearly evident at the highest investigated $\mathrm{pH}$ (lower panel).

Figures 9(a), 9(b), and 9(c) show the flow curves obtained for the higher MLSS concentration of $190 \mathrm{~g} \mathrm{~L}^{-1}$. In this case, the effect of aeration on the rheology depends on $\mathrm{pH}$ condition, as described below.

In those tests where $\mathrm{pH}$ ranged between 6.6 and 7.0 (Figure 9(a)), the effect of aeration (tests 8 and 9) led to a reduction of shear stress and apparent viscosity when the rate of deformation was below $600 \mathrm{~s}^{-1}$ or above $900 \mathrm{~s}^{-1}$; within the range (700-900) $\mathrm{s}^{-1}$ the flow curves for tests 7 (air N) and 8 (half aeration flow) were very close to each other and below the flow curve estimated for test case number 9 corresponding to fully aerated condition (air Y). This shear stress increment induced by aeration in the shear rate range (700-900) $\mathrm{s}^{-1}$ is quite scarce and apparently in contrast with the findings obtained for the $150 \mathrm{gTS} \mathrm{L}^{-1}$ sample showing that the $\mathrm{Y}$ curves are generally below the corresponding $\mathrm{N}$ curves at any shear rate (Figure 8).

Increasing the $\mathrm{pH}$ around 7.8-8.4 (Figure 9(b)), it could be noticed that if the shear rate was below $540 \mathrm{~s}^{-1}$ the aeration of sludge samples (tests 11 and 12) yielded reduction of the shear stress and apparent viscosity with respect to nonaerated sample (test 10); above this shear rate value of $540 \mathrm{~s}^{-1}$, an opposite effect was detected since the shear stress and apparent viscosity became greater in the aerated samples. In both cases, the shear stress differences between these flow curves are quite small and may be related to the interpolation procedure rather than reflecting the actual rheological behaviour.

Considering the maximum value of the $\mathrm{pH}=9.0$ (Figure $9(\mathrm{c})$ ), the shear stress and apparent viscosity for the aerated sample at full flow rate (test 15 , air $\mathrm{Y}$ ) were smaller than those obtained for the nonaerated sample (test 13, air N) when the shear rate was below $970 \mathrm{~s}^{-1}$. Above this shear rate value, the shear stress was greater for the full aerated sample. 

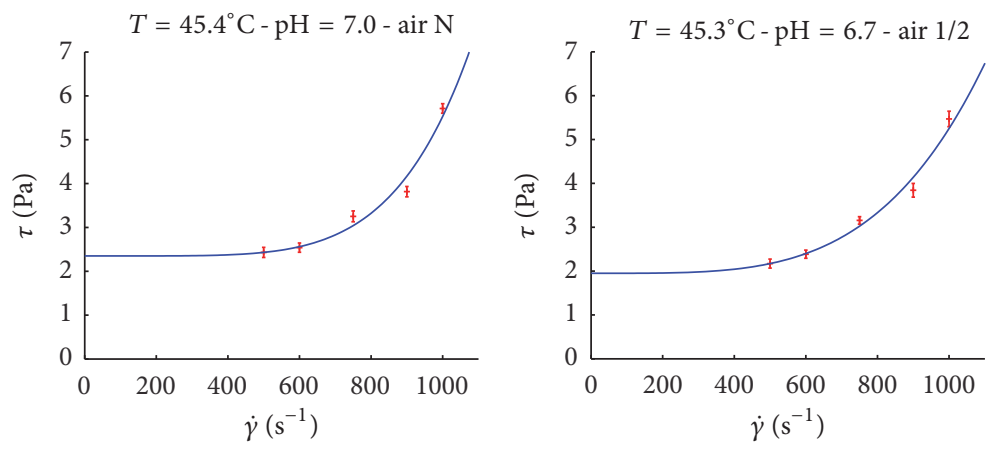

+ Exper

+ Exper

Calc

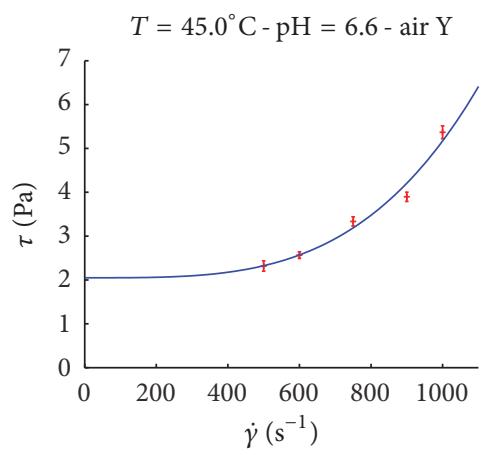

$$
\text { - Calc }
$$

Influence of aeration - $\mathrm{pH}$ 6.6-7.0 MLSS $190 \mathrm{~g} \mathrm{~L}^{-1}$

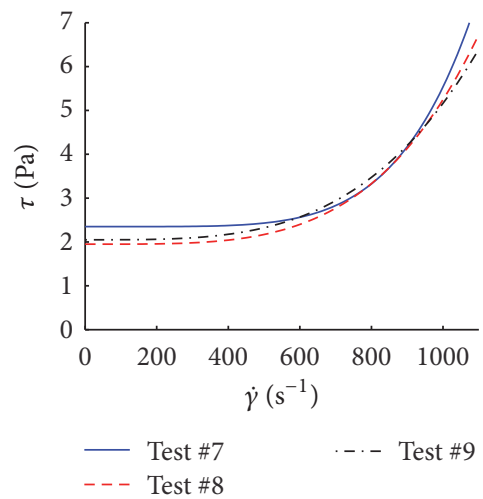

(a) Shear stress versus rate of deformation (MLSS $190 \mathrm{~g} \mathrm{~L}^{-1}$ ). Lower right-hand panel compares calculated values for $\mathrm{pH}$ condition around 6.6-7.0
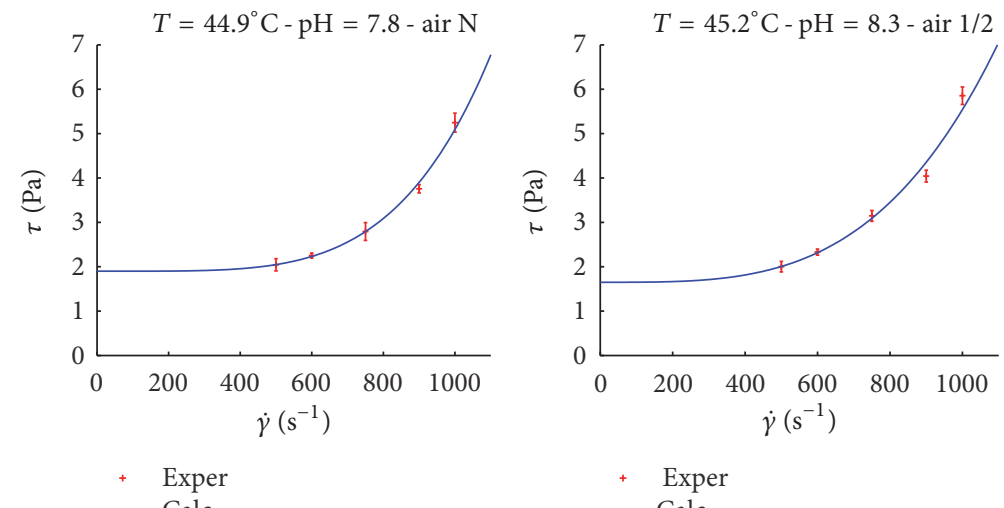

- Calc

$T=45.3^{\circ} \mathrm{C}-\mathrm{pH}=8.4-\operatorname{air} \mathrm{Y}$

Influence of aeration - $\mathrm{pH} 7.8-8.4$ MLSS $190 \mathrm{~g} \mathrm{~L}^{-1}$
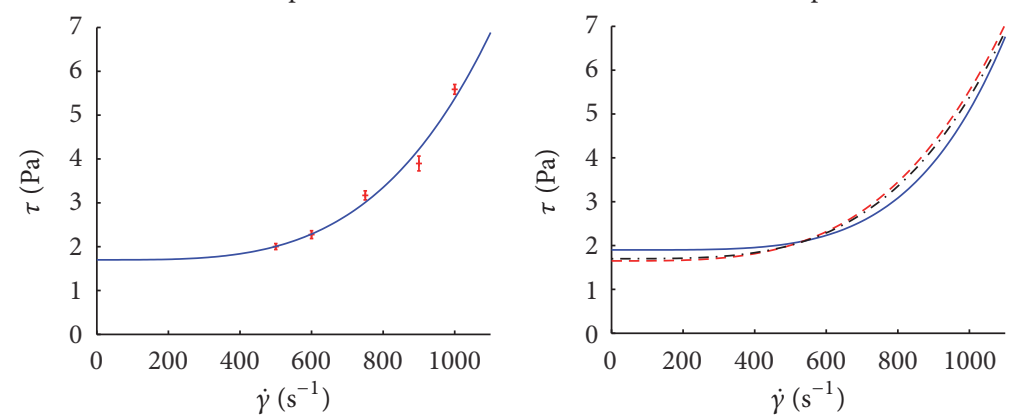

+ Exper

- Test \#10

-..- Test \#12

(b) Shear stress versus rate of deformation (MLSS $190 \mathrm{gL}^{-1}$ ). Lower right-hand panel compares calculated values for $\mathrm{pH}$ condition around 7.8-8.4

FIGURE 9: Continued. 

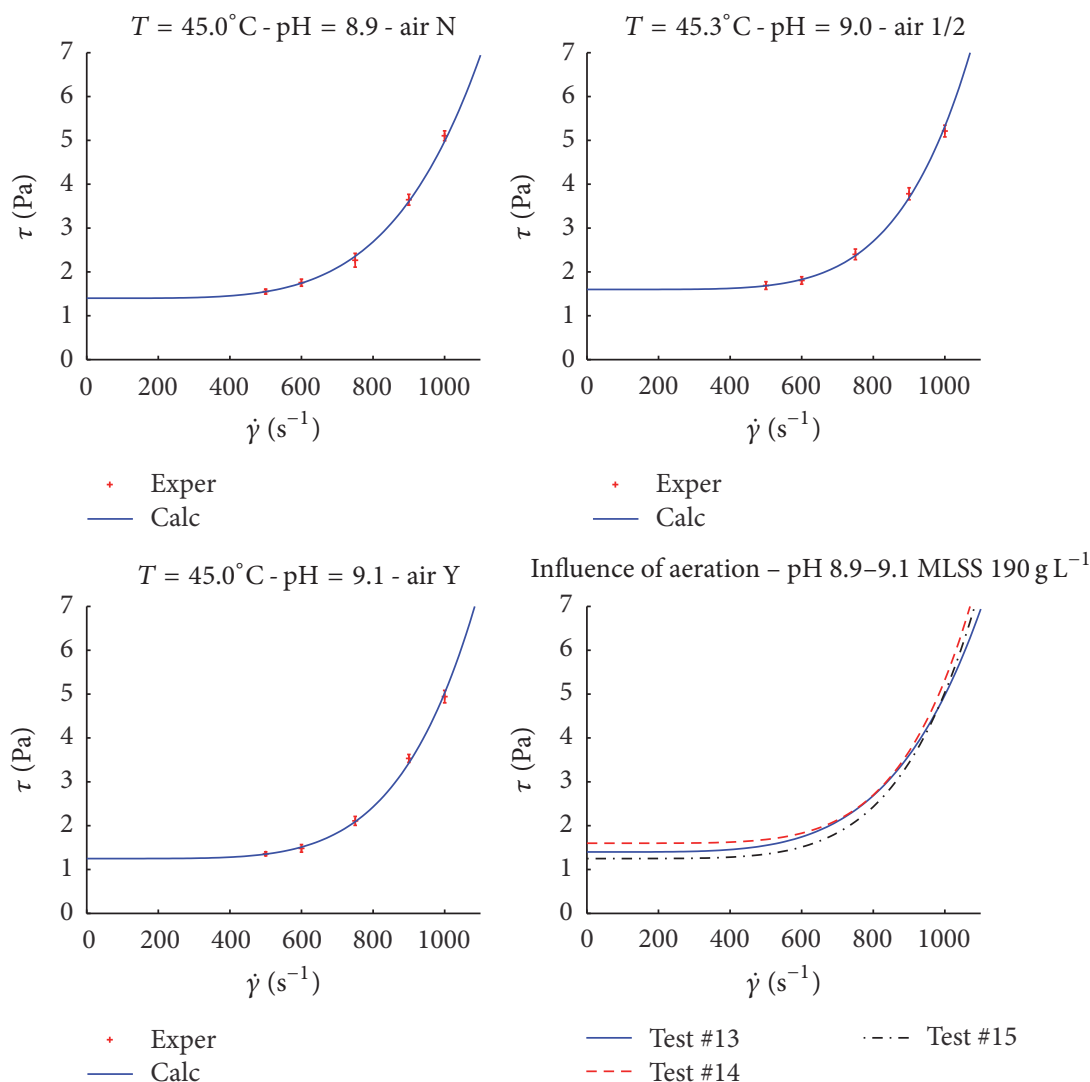

(c) Shear stress versus rate of deformation (MLSS $190 \mathrm{~g} \mathrm{~L}^{-1}$ ). Lower right-hand panel compares calculated values for $\mathrm{pH}$ condition around 8.9-9.1

Figure 9

On the contrary, the flow curve of the half aerated sample (test 14, air 1/2) never fell below the flow curve obtained from the nonaerated sample.

Based on the observation of the interpolated flow curves, the influence of aeration on the rheological behaviour of the samples appears to be not univocal: the reduction of the apparent viscosity does not take place at any shear rate for every investigated $\mathrm{pH}$ value. Furthermore, in those cases, where the obtained shear stress differences are extremely slight, such a discrepancy may be also ascribed to possible uncertainties caused by the reduced number of experimental samples available for interpolating the flow curves. Hence, further investigations are required so as to assess the influence of aeration with a higher degree of reliability.

Figure 10 shows how $\mathrm{pH}$ conditions of the nonaerated samples influence the calculated flow curves for suspended solid concentrations of $150 \mathrm{~g} \mathrm{~L}^{-1}$ (left side panel) and $190 \mathrm{~g} \mathrm{~L}^{-1}$ (right side panel).

In the case of MLSS $=150 \mathrm{~g} \mathrm{~L}^{-1}$, it can be seen that increasing the $\mathrm{pH}$ value from 6.7 (test 1) to about 7.7 (test 3) caused a negligible variation of the shear stress and apparent viscosity took place at any shear rate. Further increase of the $\mathrm{pH}$ value to 9.0 (test 5) induced, at shear rates lower than $730 \mathrm{~s}^{-1}$, a negligible increment with respect to previous curves of both shear stress and apparent viscosity, while above
$730 \mathrm{~s}^{-1}$ the shear stress decreased progressively together with the shear rate growth.

Considering the case MLSS $=190 \mathrm{~g} \mathrm{~L}^{-1}$, the observed behaviour was monotonic because, increasing $\mathrm{pH}$ values from 7.0 (test 7) to 8.9 (test 13), the shear stress and apparent viscosity diminished at any shear rate below $1000 \mathrm{~s}^{-1}$.

Figure 11 shows the influence of $\mathrm{pH}$ on the rheological behaviour of aerated sludge samples.

For the case MLSS $=150 \mathrm{~g} \mathrm{~L}^{-1}$ (left side panel), it can be seen that passing from $\mathrm{pH}=6.7$ (test 2) to $\mathrm{pH}=8.3$ (test 4 ) a negligible variation of both shear stress and apparent viscosity took place. At $\mathrm{pH}=9.1$ (test 6 ), the corresponding flow curve was always below the other two curves, resulting in a significant reduction of shear stress at higher shear rate values.

The analysis of the aerated samples with MLSS $190 \mathrm{~g} \mathrm{~L}^{-1}$ (right side panel) showed that, increasing the $\mathrm{pH}$ value with respect to test 9 , the reduction of the shear stress was significant at shear rates below $800 \mathrm{~s}^{-1}$, while above this value the flow curves corresponding to $\mathrm{pH}=8.4$ (test 12) and $\mathrm{pH}$ $=9.1$ (test 15) tended to grow faster and overcome the curve corresponding to $\mathrm{pH}=6.6$ (test 9).

Figure 12 shows the influence of $\mathrm{pH}$ on the rheological behaviour of the denser sludge samples (MLSS $190 \mathrm{~g} \mathrm{~L}^{-1}$ ) for half the aeration flow rate. The increases of $\mathrm{pH}$ value from 6.7 (test 8 ) to 8.3 (test 11) and 9.0 (test 14) led to a reduction of the 

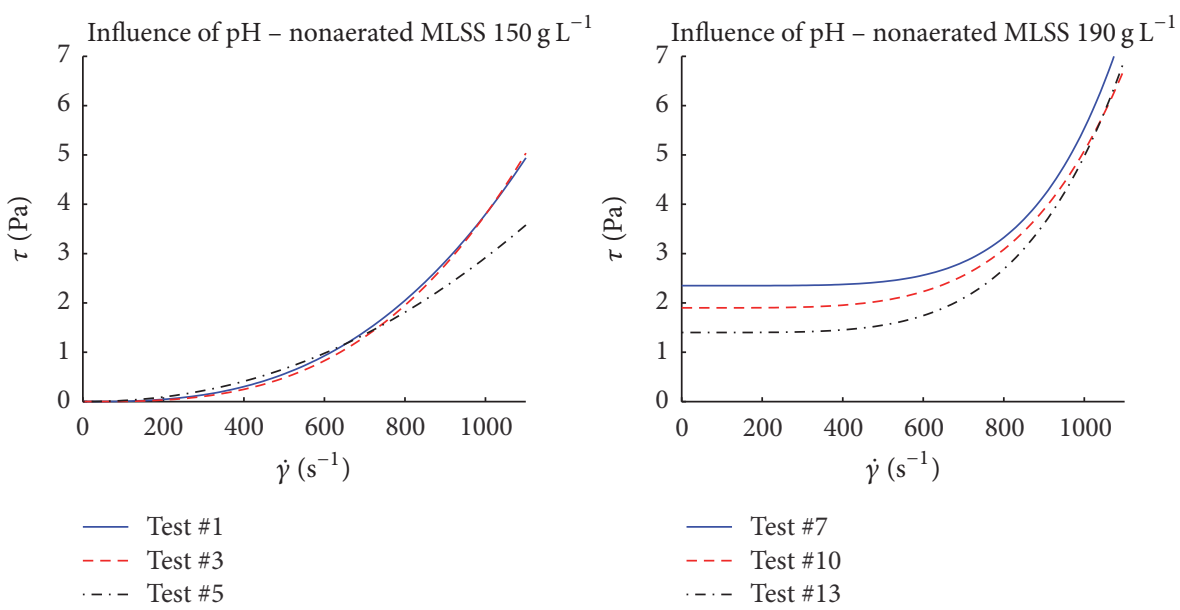

FIGURE 10: Shear stress versus rate of deformation: influence of $\mathrm{pH}$ for nonaerated samples.
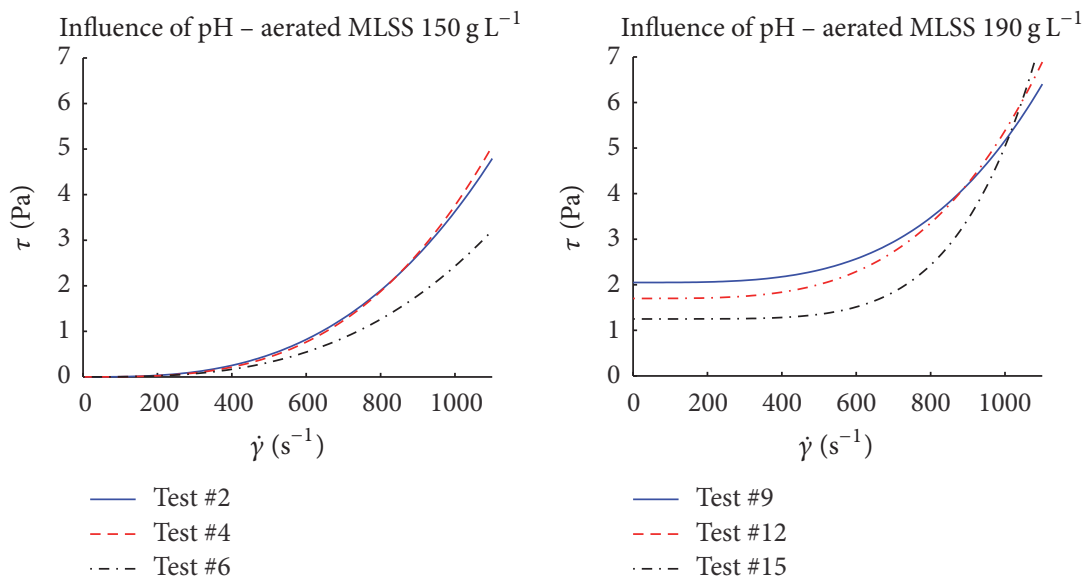

FIGURE 11: Shear stress versus rate of deformation: influence of $\mathrm{pH}$ for aerated samples.

shear stress (and following apparent viscosity) if the shear rate was below $700 \mathrm{~s}^{-1}$ and $980 \mathrm{~s}^{-1}$, respectively.

The $\mathrm{pH}$ influence on rheological behaviour might be ascribed to the bacteria aggregation extent: [90] showed that, for the activated sludge, both the values of $\tau_{y}$ and viscosity increase progressively with $\mathrm{pH}$, until it reaches a value of 7 , thus indicating that the strongest flocs cohesion occurs under weakly acidic conditions ( $\mathrm{pH}$ ranging from 6 to 7 ). Paradoxically, however, changes of the zeta potential as a function of $\mathrm{pH}$ highlight that it is strongly negative for values from 6 to 7 , with the isopotential conditions being quite far.

In a subsequent study [59], some tests on activated sludge from both aeration tanks and laboratory scale pilot plants were carried out using rotational rheometer. Although the MLSS concentration was lower than $10 \mathrm{~g} \mathrm{~L}^{-1}$, a similar influence of $\mathrm{pH}$ on the mechanical properties of sludge was found. In particular, the yield stress $\tau_{y}$ decreased after chlorination, denoting a possible deflocculation.

The samples studied in $[59,90]$ have a MLSS concentration significantly lower than those tested in the present research: further analyses will be necessary to explore the behaviour of a highly concentrated sludge.

\section{Conclusions}

The population profile differed clearly from a typical profile of municipal as well as industrial wastewater treatment plants. Notable is the missing of several of the major bacteria groups and the low diversity within the present major bacteria groups. Beside the considerably dominating Betaproteobacteria, only a few other main bacteria groups were present showing only very limited diversity within the groups. The remaining organisms seemed to be adapted to the extreme conditions applied and the obtained population profile was very different from typical profiles from other WWTPs with "normal" temperature conditions. All in all, the extreme temperature conditions seem to trigger the surviving of the (fittest) "most adapted" organisms to the conditions applied. Also, the almost complete absence of filamentous bacteria is a typical feature of thermophilic aerobic sludge treatment and can lead to sludge losses due to the inability to form stable sludge flocs.

This early phase of the study was focused on a limited number of shear rate values: nevertheless, the first results provide a valuable insight into the rheological behaviour of 


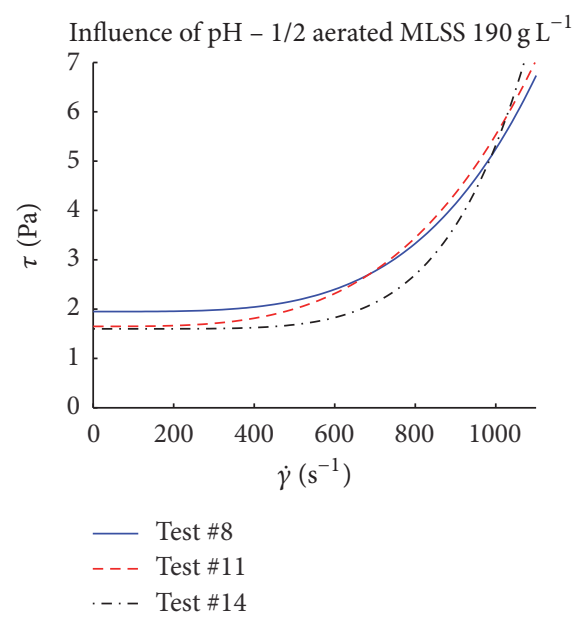

FIGURE 12: Shear stress versus rate of deformation: influence of $\mathrm{pH}$ for $1 / 2$ aerated samples.

a highly concentrated thermophilic sludge. Furthermore, the trend of the flow curves shows a certain degree of reliability, as corroborated by the regression coefficients.

The influence of some relevant operative parameters (i.e., $\mathrm{pH}$, temperature, biomass concentration, and aeration within the biological reactor) on the rheological behaviour of the activated sludge was confirmed, thus providing valuable guidelines for an efficient management of the wastewater treatment process. The effects of aeration were sometimes not univocal and reveal an opposing behaviour depending on the values of the other parameters. This aspect may be related to possible uncertainties connected to the low number of samples available for the interpolation of the flow curves, thus resulting in small discrepancy between them. Therefore, it will be better investigated within a future study.

The rheological behaviour affects significantly the treatment processes of TAMR systems because, with respect to conventional processes involving activated sludge, the major part of the energy demand is connected to the use of membranes and is strongly affected by the suspended solid concentration and the biomass viscosity.

The analyses carried out show that the rheological behaviour of TAMR biomass is mainly affected by MLSS concentration.

The sludge exhibited shear-thickening (dilatant) behaviour; at MLSS concentration of $150 \mathrm{~g} \mathrm{~L}^{-1}$, the estimated yield $\tau_{y}$ stress was equal to zero, but when MLSS concentration reached $190 \mathrm{gL}^{-1}$, the interactions between the sludge particles were expected to be even more intense and therefore a nonzero yield stress was observed. As a consequence, increasing the biomass concentration, up to $190 \mathrm{gTS} \mathrm{L}^{-1}$, could provide important information, in terms of rheological behaviour, for the optimal management of thermophilic process.

\section{Conflicts of Interest}

The authors declare that there are no conflicts of interest regarding the publication of this paper.

\section{References}

[1] P. Madoni, "A sludge biotic index (SBI) for the evaluation of the biological performance of activated sludge plants based on the microfauna analysis," Water Research, vol. 28, no. 1, pp. 67-75, 1994.

[2] P. Madoni, "Protozoa in wastewater treatment processes: A minireview," Italian Journal of Zoology, vol. 78, no. 1, pp. 3-11, 2011.

[3] E. Castillo González, L. De Medina Salas, and A. Contreras Gutiérrez, "A practical procedure for the microbiological monitoring of activated sludge plant functioning," Water and Environment Journal, vol. 30, no. 3-4, pp. 182-189, 2016.

[4] C. Leal, A. L. Amaral, and M. D. L. Costa, "Microbial-based evaluation of foaming events in full-scale wastewater treatment plants by microscopy survey and quantitative image analysis," Environmental Science and Pollution Research, vol. 23, no. 15, pp. 15638-15650, 2016.

[5] F. Fang, B.-J. Ni, X.-Y. Li, G.-P. Sheng, and H.-Q. Yu, "Kinetic analysis on the two-step processes of $\mathrm{AOB}$ and NOB in aerobic nitrifying granules," Applied Microbiology and Biotechnology, vol. 83, no. 6, pp. 1159-1169, 2009.

[6] R. Cui, W.-J. Chung, and D. Jahng, "A rapid and simple respirometric biosensor with immobilized cells of Nitrosomonas europaea for detecting inhibitors of ammonia oxidation," Biosensors and Bioelectronics, vol. 20, no. 9, pp. 1788-1795, 2005.

[7] M. Saryoglu and F. Ciner, "Investigation of OUR and NUR experiments for nitrogen and phosphorus removal with activated sludge: A lab-scale study," International Journal of Environment and Pollution, vol. 19, no. 6, pp. 635-643, 2003.

[8] M. Hagman, J. L. Nielsen, P. H. Nielsen, and J. L. C. Jansen, "Mixed carbon sources for nitrate reduction in activated sludgeidentification of bacteria and process activity studies," Water Research, vol. 42, no. 6-7, pp. 1539-1546, 2008.

[9] A. Mielcarek, J. Rodziewicz, W. Janczukowicz et al., "Citric acid application for denitrification process support in biofilm reactor," Chemosphere, vol. 171, pp. 512-519, 2017.

[10] Q. Feng, Y. Xiao, X. Li et al., "Using the dehydrogenase activity for alert of activated sludge system under different copper concentrations," Desalination and Water Treatment, vol. 57, no. 38, pp. 17836-17843, 2016.

[11] M. Ghribi, F. Meddeb-Mouelhi, and M. Beauregard, "Microbial diversity in various types of paper mill sludge: identification of enzyme activities with potential industrial applications," SpringerPlus, vol. 5, no. 1, article no. 1492, 2016.

[12] D. Jenkins, M. G. Richard, and G. T. Daigger, Manual on The Causes and Control of Activated Sludge Bulking and Foaming, Lewis Publishers, CRC Press LLC, 2004.

[13] D. Eikelboom, "Identification and Control of Filamentous Micro-organisms in Industrial Wastewater Treatment Plants," in Multi-Media Training CD, IWA, International Water Association, 2006.

[14] B. Hu, R. Qi, W. An et al., "Dynamics of the microfauna community in a full-scale municipal wastewater treatment plant experiencing sludge bulking," European Journal of Protistology, vol. 49, no. 4, pp. 491-499, 2013.

[15] H. Salvadó, "Improvement of the intersection method for the quantification of filamentous organisms: Basis and practice for bulking and foaming bioindication purposes," Water Science and Technology, vol. 74, no. 6, pp. 1274-1282, 2016.

[16] L. Arregui, R. Liébana, E. Rodríguez et al., "Analysis of the usefulness of biological parameters for the control of activated 
sludge wastewater treatment plants in an interlaboratory study context," Journal of Environmental Monitoring, vol. 14, no. 5, pp. 1444-1452, 2012.

[17] B. Pérez-Uz, L. Arregui, P. Calvo et al., "Assessment of plausible bioindicators for plant performance in advanced wastewater treatment systems," Water Research, vol. 44, no. 17, pp. 50595069, 2010.

[18] G. Łagód, R. Babko, K. Jaromin-Gleń, T. Kuzmina, and A. Bieganowski, "Biofilm Communities in Successive Stages of Municipal Wastewater Treatment," Environmental Engineering Science, vol. 33, no. 5, pp. 306-316, 2016.

[19] W. Foissner, "Protists as bioindicators in activated sludge: Identification, ecology and future needs," European Journal of Protistology, vol. 55, pp. 75-94, 2016.

[20] A. L. Amaral, M. Da Motta, M. N. Pons et al., "Survey of Protozoa and Metazoa populations in wastewater treatment plants by image analysis and discriminant analysis," Environmetrics, vol. 15, no. 4, pp. 381-390, 2004.

[21] H. Lu, K. Chandran, and D. Stensel, "Microbial ecology of denitrification in biological wastewater treatment," Water Research, vol. 64, pp. 237-254, 2014.

[22] M. Tian, F. Zhao, X. Shen et al., "The first metagenome of activated sludge from full-scale anaerobic/anoxic/oxic (A2O) nitrogen and phosphorus removal reactor using Illumina sequencing," Journal of Environmental Sciences, vol. 35, pp. 181190, 2015.

[23] X.-R. Li, Y. Lv, H. Meng, J.-D. Gu, and Z.-X. Quan, "Analysis of microbial diversity by pyrosequencing the small-subunit ribosomal RNA without PCR amplification," Applied Microbiology and Biotechnology, vol. 98, no. 8, pp. 3777-3789, 2014.

[24] P. Asvapathanagul and B. H. Olson, "Improving qPCR methodology for detection of foaming bacteria by analysis of broad-spectrum primers and a highly specific probe for quantification of Nocardia spp. in activated sludge," Journal of applied microbiology, vol. 122, no. 1, pp. 97-105, 2017.

[25] R. Ferrentino, M. Langone, I. Gandolfi, V. Bertolini, A. Franzetti, and G. Andreottola, "Shift in microbial community structure of anaerobic side-stream reactor in response to changes to anaerobic solid retention time and sludge interchange ratio," Bioresource Technology, vol. 221, pp. 588-597, 2016.

[26] I. Ferrera and O. Sánchez, "Insights into microbial diversity in wastewater treatment systems: How far have we come?" Biotechnology advances, vol. 34, no. 5, pp. 790-802, 2016.

[27] L. Faust, M. Szendy, C. M. Plugge, P. F. H. van den Brink, H. Temmink, and H. H. M. Rijnaarts, "Characterization of the bacterial community involved in the bioflocculation process of wastewater organic matter in high-loaded MBRs," Applied Microbiology and Biotechnology, vol. 99, no. 12, pp. 5327-5337, 2015.

[28] D. Xu, S. Liu, Q. Chen, and J. Ni, "Microbial community compositions in different functional zones of Carrousel oxidation ditch system for domestic wastewater treatment," AMB Express, vol. 7, no. 1, p. 40, 2017.

[29] B. Hu, R. Qi, and M. Yang, "Systematic analysis of microfauna indicator values for treatment performance in a full-scale municipal wastewater treatment plant," Journal of Environmental Sciences, vol. 25, no. 7, pp. 1379-1385, 2013.

[30] A. Drzewicki and D. Kulikowska, "Limitation of Sludge Biotic Index application for control of a wastewater treatment plant working with shock organic and ammonium loadings," European Journal of Protistology, vol. 47, no. 4, pp. 287-294, 2011.
[31] K. Zhou, M. Xu, J. Dai, and H. Cao, "The microfauna communities and operational monitoring of an activated sludge plant in China," European Journal of Protistology, vol. 42, no. 4, pp. 291-295, 2006.

[32] M.-K. H. Winkler, E. Kröber, W. W. Mohn, F. Koch, and D. Frigon, "Comparison of microbial populations and foaming dynamics in conventional versus membrane enhanced biological phosphorous removal systems," Water and Environment Journal, vol. 30, no. 1-2, pp. 102-112, 2016.

[33] Y. Deng, X. Zhang, Y. Miao, and B. Hu, "Exploration of rapid start-up of the CANON process from activated sludge inoculum in a sequencing biofilm batch reactor (SBBR)," Water Science and Technology, vol. 73, no. 3, pp. 535-542, 2016.

[34] S. Rodriguez-Perez and F. G. Fermoso, "Influence of an oxic settling anoxic system on biomass yield, protozoa and filamentous bacteria," Bioresource Technology, vol. 200, pp. 170-177, 2016.

[35] R. Pedrazzani, L. Menoni, S. Nembrini, L. Manili, and G. Bertanza, "Suitability of Sludge Biotic Index (SBI), Sludge Index (SI) and filamentous bacteria analysis for assessing activated sludge process performance: the case of piggery slaughterhouse wastewater," Journal of Industrial Microbiology and Biotechnology, vol. 43, no. 7, pp. 953-964, 2016.

[36] L. Araújo dos Santos, V. Ferreira, M. O. Pereira, and A. Nicolau, "Relationship between protozoan and metazoan communities and operation and performance parameters in a textile sewage activated sludge system," European Journal of Protistology, vol. 50, no. 4, pp. 319-328, 2014.

[37] G. Morales, S. Pesante, and G. Vidal, "Effects of black liquor shocks on activated sludge treatment of bleached kraft pulp mill wastewater," Journal of Environmental Science and Health - Part A, vol. 50, no. 6, pp. 639-645, 2015.

[38] A. L. Leal, M. S. Dalzochio, T. S. Flores, A. S. De Alves, J. C. Macedo, and V. H. Valiati, "Implementation of the sludge biotic index in a petrochemical WWTP in Brazil: Improving operational control with traditional methods," Journal of Industrial Microbiology and Biotechnology, vol. 40, no. 12, pp. 1415-1422, 2013.

[39] J. Jena, R. Kumar, M. Saifuddin, A. Dixit, and T. Das, "Anoxicaerobic SBR system for nitrate, phosphate and COD removal from high-strength wastewater and diversity study of microbial communities," Biochemical Engineering Journal, vol. 105, pp. 80 89, 2016.

[40] B. J. Thwaites, P. Reeve, N. Dinesh, M. D. Short, and B. van den Akker, "Comparison of an anaerobic feed and split anaerobicaerobic feed on granular sludge development, performance and ecology," Chemosphere, vol. 172, pp. 408-417, 2017.

[41] M. Matsubayashi, Y. Shimada, Y. Y. Li, H. Harada, and K. Kubota, "Phylogenetic diversity and in situ detection of eukaryotes in anaerobic sludge digesters," PloS one, vol. 12, no. 3, Article ID e0172888, 2017.

[42] G. Wang, X. Xu, Z. Gong, F. Gao, F. Yang, and H. Zhang, "Study of simultaneous partial nitrification, ANAMMOX and denitrification (SNAD) process in an intermittent aeration membrane bioreactor," Process Biochemistry, vol. 51, no. 5, pp. 632-641, 2016.

[43] S. Ge, S. Wang, X. Yang, S. Qiu, B. Li, and Y. Peng, "Detection of nitrifiers and evaluation of partial nitrification for wastewater treatment: A review," Chemosphere, vol. 140, pp. 85-98, 2015.

[44] Y. Liu, Y. Yuan, X. Li, X. Kang, and M. Du, "Succession of bacterial community in anaerobic-anoxic-aerobic (A2O) bioreactor using sludge fermentation liquid as carbon source," 
Desalination and Water Treatment, vol. 54, no. 4-5, pp. 10611069, 2015.

[45] C. M. Fitzgerald, P. Camejo, J. Z. Oshlag, and D. R. Noguera, "Ammonia-oxidizing microbial communities in reactors with efficient nitrification at low-dissolved oxygen," Water Research, vol. 70, pp. 38-51, 2015.

[46] P. Regmi, B. Holgate, D. Fredericks et al., "Optimization of a mainstream nitritation-denitritation process and anammox polishing," Water Science and Technology, vol. 72, no. 4, pp. 632642, 2015.

[47] P. Cornel, M. Wagner, and S. Krause, "Investigation of oxygen transfer rates in full scale membrane bioreactors," Water Science and Technology, vol. 47, no. 11, Article ID 313e319, 2003.

[48] B. De Clercq, Computational Fluid Dynamics of Settling Tanks: Development of Experiments and Rheological, Settling and Scraper Submodels [Ph.D. thesis], Ghent University, 2003.

[49] I. Seyssiecq, J.-H. Ferrasse, and N. Roche, "State-of-the-art: Rheological characterisation of wastewater treatment sludge," Biochemical Engineering Journal, vol. 16, no. 1, pp. 41-56, 2003.

[50] G. Tchobanoglous, F. L. Burton, and H. D. Stensel, Wastewater Engineering: Treatment and Reuse, McGraw-Hill, Boston, 2003.

[51] F. Yang, A. Bick, S. Shandalov, A. Brenner, and G. Oron, "Yield stress and rheological characteristics of activated sludge in an airlift membrane bioreactor," Journal of Membrane Science, vol. 334, no. 1-2, pp. 83-90, 2009.

[52] M. Brannock, G. Leslie, Y. Wang, and S. Buetehorn, "Optimising mixing and nutrient removal in membrane bioreactors: CFD modelling and experimental validation," Desalination, vol. 250, no. 2, Article ID 815e818, 2010.

[53] S. Todeschini, C. Ciaponi, and S. Papiri, "Laboratory Experiments and Numerical Modelling of the Scouring Effects of Flushing Waves on Sediment Beds," Engineering Applications of Computational Fluid Mechanics, vol. 4, no. 3, pp. 365-373, 2010.

[54] K. J. Craig, M. N. Nieuwoudt, and L. J. Niemand, "CFD simulation of anaerobic digester with variable sewage sludge rheology," Water Research, vol. 47, no. 13, pp. 4485-4497, 2013.

[55] R. Hreiz, M. A. Latifi, and N. Roche, "Optimal design and operation of activated sludge processes: State-of-the-art," Chemical Engineering Journal, vol. 281, pp. 900-920, 2015.

[56] A. Asadi, A. A. L. Zinatizadeh, and M. Hasnain Isa, "Performance of intermittently aerated up-flow sludge bed reactor and sequencing batch reactor treating industrial estate wastewater: A comparative study," Bioresource Technology, vol. 123, pp. 495506, 2012.

[57] G. Moeller and L. G. Torres, "Rheological characterization of primary and secondary sludges treated by both aerobic and anaerobic digestion," Bioresource Technology, vol. 61, no. 3, pp. 207-211, 1997.

[58] N. Tixier, G. Guibaud, and M. Baudu, "Determination of some rheological parameters for the characterization of activated sludge," Bioresource Technology, vol. 90, no. 2, pp. 215-220, 2003.

[59] G. Guibaud, P. Dollet, N. Tixier, C. Dagot, and M. Baudu, "Characterisation of the evolution of activated sludges using rheological measurements," Process Biochemistry, vol. 39, no. 11, pp. 1803-1810, 2004.

[60] H. Hasar, C. Kinaci, A. Ünlü, H. Toğrul, and U. Ipek, "Rheological properties of activated sludge in a sMBR," Biochemical Engineering Journal, vol. 20, no. 1, pp. 1-6, 2004.

[61] G. Laera, C. Giordano, A. Pollice, D. Saturno, and G. Mininni, "Membrane bioreactor sludge rheology at different solid retention times," Water Research, vol. 41, no. 18, pp. 4197-4203, 2007.
[62] S. Manenti, E. Pierobon, M. Gallati et al., "Vajont disaster: Smoothed particle hydrodynamics modeling of the postevent 2D experiments," Journal of Hydraulic Engineering, vol. 142, no. 4, 2015.

[63] R. Guandalini, G. Agate, S. Manenti, S. Sibilla, and M. Gallati, "SPH based approach toward the simulation of non-cohesive sediment removal by an innovative technique using a controlled sequence of underwater micro-explosions," Procedia IUTAM, vol. 18, pp. 28-39, 2015.

[64] S. Manenti, S. Sibilla, M. Gallati, G. Agate, and R. Guandalini, "SPH Simulation of Sediment Flushing Induced by a Rapid Water Flow," Journal of Hydraulic Engineering, vol. 138, no. 3, pp. 272-284, 2012.

[65] S. Baroutian, N. Eshtiaghi, and D. J. Gapes, "Rheology of a primary and secondary sewage sludge mixture: Dependency on temperature and solid concentration," Bioresource Technology, vol. 140, pp. 227-233, 2013.

[66] P. T. Slatter, "The rheological characterisation of sludges," Water Science and Technology, vol. 36, no. 11, pp. 9-18, 1997.

[67] M. Mori, I. Seyssiecq, and N. Roche, "Rheological measurements of sewage sludge for various solids concentrations and geometry," Process Biochemistry, vol. 41, no. 7, pp. 1656-1662, 2006.

[68] N. Ratkovich, W. Horn, F. P. Helmus et al., "Activated sludge rheology: A critical review on data collection and modelling," Water Research, vol. 47, no. 2, pp. 463-482, 2013.

[69] F. D. Sanin, "Effect of solution physical chemistry on the rheological properties of activated sludge," Water $S A$, vol. 28, no. 2, pp. 207-211, 2002.

[70] O. Manoliadis and P. L. Bishop, "Temperature effect on rheology of sludges," Journal of Environmental Engineering, vol. 110, no. 1, pp. 286-290, 1984.

[71] J. C. Baudez, P. Slatter, and N. Eshtiaghi, "The impact of temperature on the rheological behaviour of anaerobic digested sludge," Chemical Engineering Journal, vol. 215-216, pp. 182-187, 2013.

[72] M. Papa, R. Pedrazzani, S. Nembrini, and G. Bertanza, "Should rheological properties of activated sludge be measured?" Applied Rheology, vol. 25, no. 2, Article ID 24590, 2015.

[73] S. J. Jahren, J. A. Rintala, and H. Ødegaard, "Aerobic moving bed biofilm reactor treating thermomechanical pulping whitewater under thermophilic conditions," Water Research, vol. 36, no. 4, pp. 1067-1075, 2002.

[74] A. Rozich and K. Bordacs, "Use of thermophilic biological aerobic technology for industrial wastewater treatment," Water Science and Technology, vol. 46, no. 4-5, pp. 83-89, 2002.

[75] R. Kurian, C. Acharya, G. Nakhla, and A. Bassi, "Conventional and thermophilic aerobic treatability of high strength oily pet food wastewater using membrane-coupled bioreactors," Water Research, vol. 39, no. 18, pp. 4299-4308, 2005.

[76] M. C. Collivignarelli, A. Abbà, and G. Bertanza, “Treatment of high strength pharmaceutical wastewaters in a Thermophilic Aerobic Membrane Reactor (TAMR)," Water Research, vol. 63, pp. 190-198, 2014.

[77] M. C. Collivignarelli, F. Castagnola, M. Sordi, and G. Bertanza, "Treatment of sewage sludge in a thermophilic membrane reactor (TMR) with alternate aeration cycles," Journal of Environmental Management, vol. 162, pp. 132-138, 2015a.

[78] T. M. Lapara and J. E. Alleman, "Thermophilic aerobic biological wastewater treatment," Water Research, vol. 33, no. 4, pp. 895-908, 1999. 
[79] M. C. Collivignarelli, A. Abbà, and G. Bertanza, "Why use a thermophilic aerobic membrane reactor for the treatment of industrial wastewater/liquid waste?" Environmental Technology, vol. 36, no. 16, pp. 2115-2124, 2015b.

[80] M. C. Collivignarelli, G. Bertanza, M. Sordi, and R. Pedrazzani, "High-strength wastewater treatment in a pure oxygen thermophilic process: 11-year operation and monitoring of different plant configurations," Water Science and Technology, vol. 71, no. 4, pp. 588-596, 2015c.

[81] A. F. Rozich, R. J. Colvin, and C. D. Hahn, "Design and Operation of a High Strength Organic Wastewater Treatment System to Approach Zero Net Sludge Production at A Specialty Chemical Plant," in Proceedings of the Water Environment Federation, vol. 2004, pp. 373-388, Biotec Company, West Chester, Pennsylvania.

[82] J. C. T. Vogelaar, A. De Keizer, S. Spijker, and G. Lettinga, "Bioflocculation of mesophilic and thermophilic activated sludge," Water Research, vol. 39, no. 1, pp. 37-46, 2005.

[83] B. Q. Liao, H. J. Lin, S. P. Langevin, W. J. Gao, and G. G. Leppard, "Effects of temperature and dissolved oxygen on sludge properties and their role in bioflocculation and settling," Water Research, vol. 45, no. 2, pp. 509-520, 2011.

[84] J. Suvilampi, A. Lehtomäki, and J. Rintala, "Comparative study of laboratory-scale thermophilic and mesophilic activated sludge processes," Water Research, vol. 39, no. 5, pp. 741-750, 2005.

[85] J. Suvilampi, A. Lehtomäki, and J. Rintala, "Biomass characterization of laboratory-scale thermophilic-mesophilic wastewater treatment processes," Environmental Technology, vol. 27, no. 1, pp. 41-51, 2006.

[86] F. Morgan-Sagastume and D. G. Allen, "Effects of temperature transient conditions on aerobic biological treatment of wastewater," Water Research, vol. 37, no. 15, pp. 3590-3601, 2003.

[87] B.-M. Wilén, B. Jin, and P. Lant, "Impacts of structural characteristics on activated sludge floc stability," Water Research, vol. 37, no. 15, pp. 3632-3645, 2003.

[88] B.-M. Wilén, M. Onuki, M. Hermansson, D. Lumley, and T. Mino, "Microbial community structure in activated sludge floc analysed by fluorescence in situ hybridization and its relation to floc stability," Water Research, vol. 42, no. 8-9, pp. 2300-2308, 2008.

[89] L. H. Mikkelsen, "The shear sensitivity of activated sludge: Relations to filterability, rheology and surface chemistry," Colloids and Surfaces A: Physicochemical and Engineering Aspects, vol. 182, no. 1-3, pp. 1-14, 2001.

[90] P. Dollet, Application rhéologique à la caractérisation de l'état de floculation des boues activées [Ph.D. thesis], Université dee Limoges, 2000. 

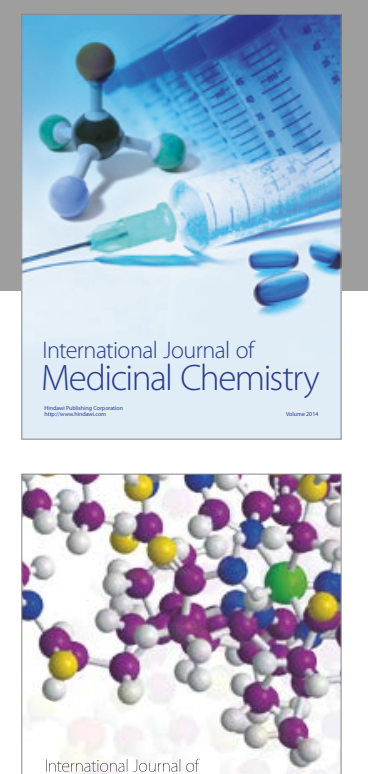

Carbohydrate Chemistry

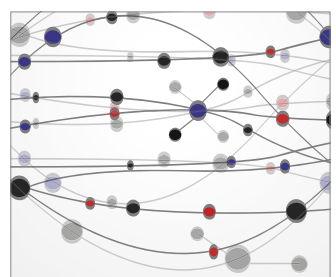

The Scientific World Journal
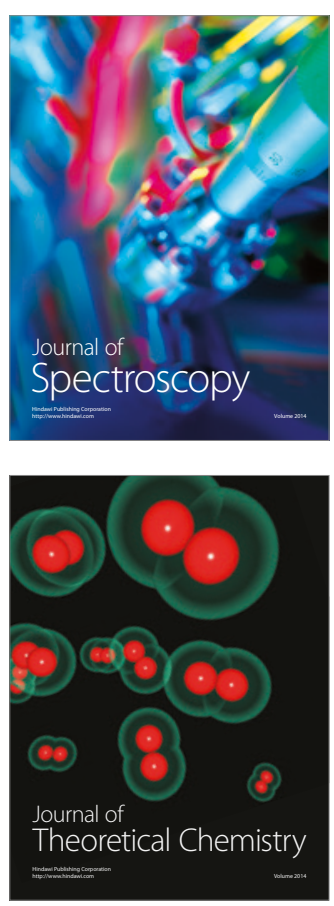
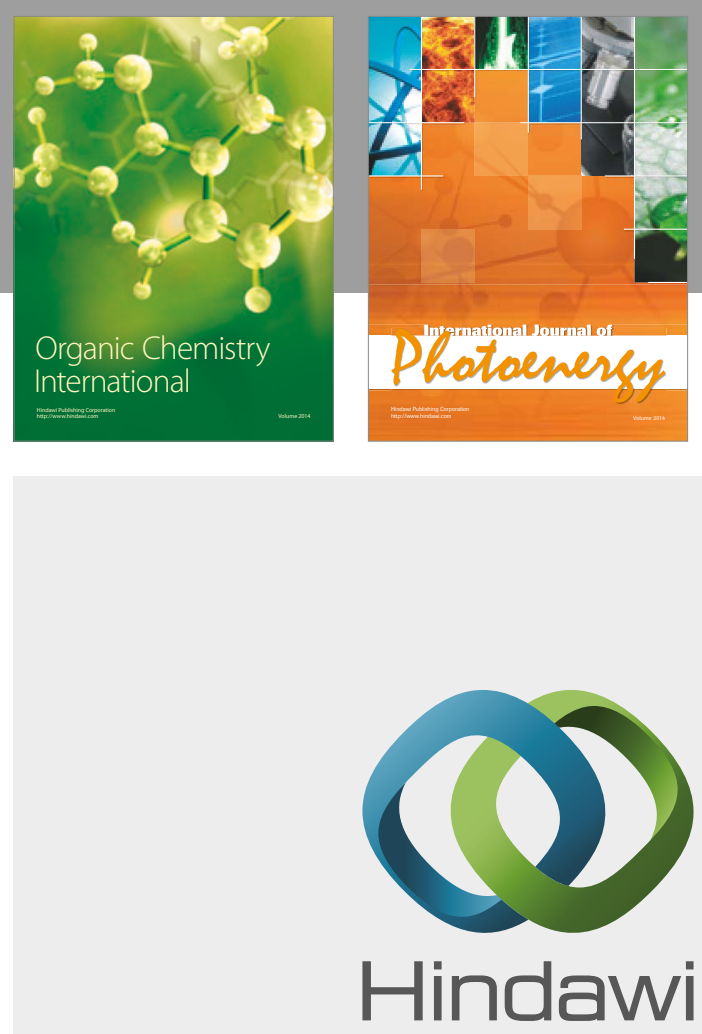

Submit your manuscripts at

https://www.hindawi.com

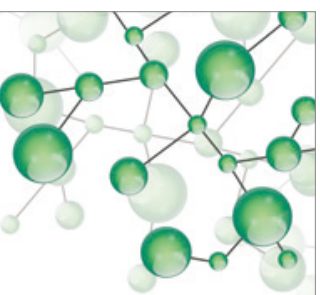

International Journal of

Inorganic Chemistry

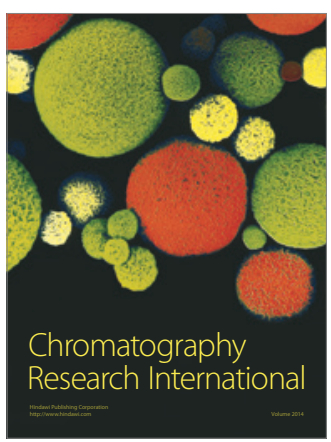

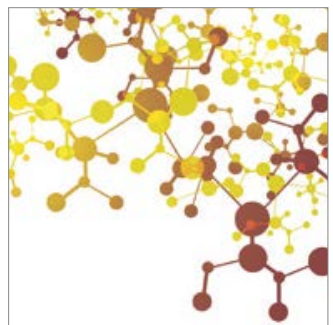

Applied Chemistry
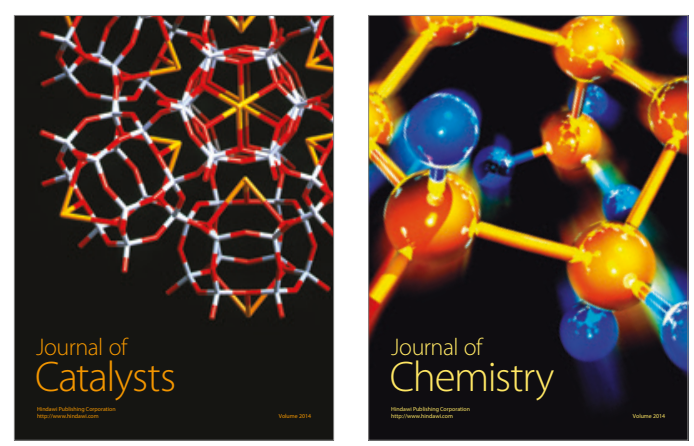
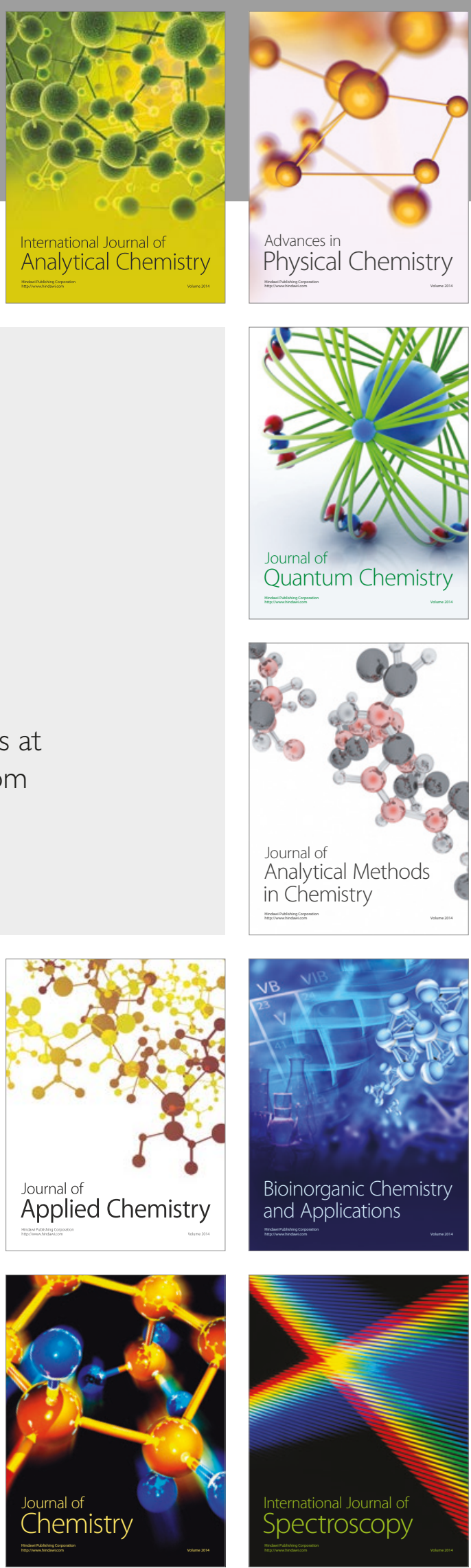